\title{
العلوم الدينية في واسط في القرنين السابع والثاهن الهجريين
}

م.د. سلتو منزن فاضل كاظم

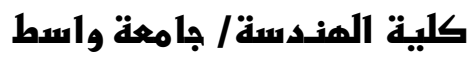

الاقدهمة:

لمدينة و اسط تاريخ عريق حافل بالانجاز ات، لاسيما العلمية منها، اذ شهدت المدينة على تاريخها في العصور الاسلامية ظهور علماء كبار بزغ نجمهم في سماء العلم و المعرفة حتى صـارت و اسط مركز اً للعلم و التعليم يقصده طلبة العلم من شتى بقاع الدنيا. وكان العلم الأكثر وضوحاً في مسيرة علمـاء واسط هو العلوم الدينية، بمـا تتضمنه من علوم القر اءات و التفسير و الحديث و الفقه، كما ان هذه المدينة لم تتأثر مسيرتها الحياتية بعد سبطرة المغول على العر اق، بل استمرت الحركة العلمية فيها، و هذا ما جعلنا نختار موضوع (العلوم الدينية في واسط في القرنين السابع و الثامن الهجريين)، في محاولة منا لاظهار هذه المعارف لمدينة واسط انذالك.

\section{اولأ- علوم القرآن الكريميم}

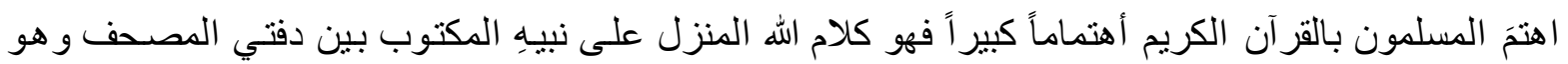

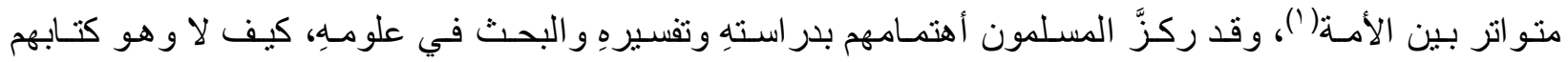
المقد، ودستور هم في تنظيم شؤون حياتهم والركيزة الرئيسة التي قامت عليها الحركة العلمية في العالم الإسـلامي،

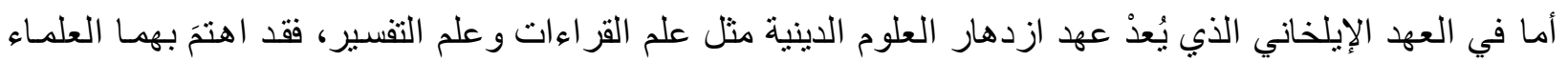
على الرغم من الأضطر اب السياسي الذي كان ير افق تللك العهود وكان بمثابة ردة فعل لعلماء المسلمين على الوضع

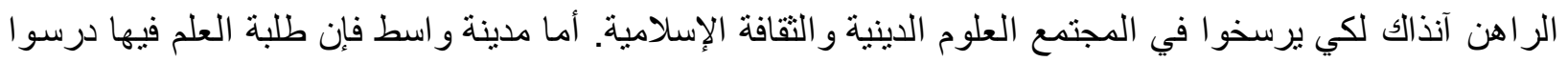
جميع الكتب التي كانت تلبي متطلبات المجتمع، وبهذا أتقنو القراءة و الكتابة التي ركزوا عليها أثناء مسيرتهم العلمية وكان من ضمن العلوم المثقنة: اللغة العربية وفنونها وقر اءة الثـعر، فضـلاً عن علوم القرآن الكريم الذي حظيَّ بالعناية و الدرس من قبل المفسرين و القُر اء حيث تتـاولو ا تفسيرهُ ومجازهُ وبديعه و أمثالده وحروفهه ومتشـابهاه وناسخه

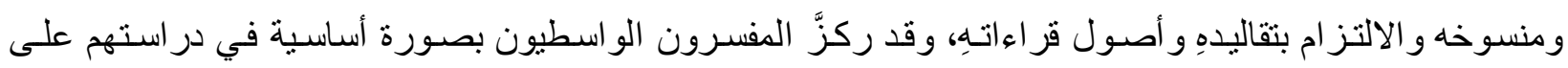
القر آن الكريم ومـا شـمل من علوم مثل التفسير والقر اءات و الحديث والققه وغيره من العلوم الدينية و استطاعو ا الإبداع في تللك العلوم، حتى وصفهم إبن بطوطة بقوله:(( أكثر هم يحفظون القرآن الكريم ويجيدون تجويده بـالقر اءة

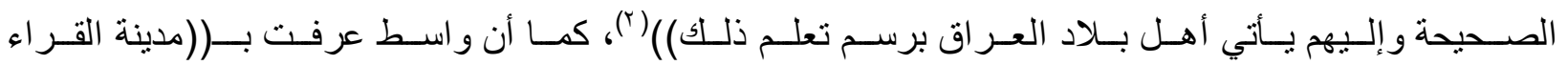

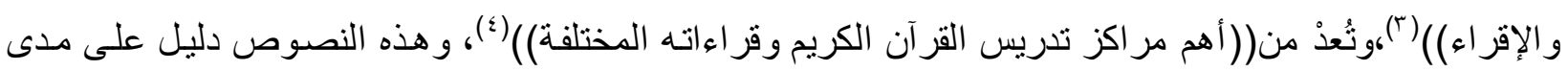
إتقان أهل و اسط لعلوم القرآن الكريم. أما علوم القرآن التي تتاولها أهل و اسط فهي:

\section{اولاً- علم القراءات}

و هو علمُ يُبحَثْْ فيه عن صور نظم كلام الله تعالى من حيث وجوه الأختلافات المتواترة، ولهُ أمتداد في

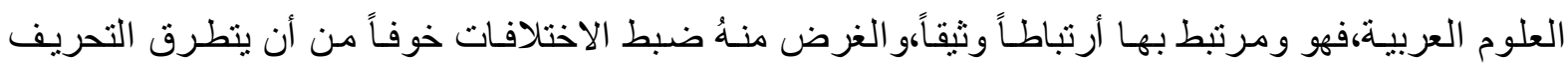
و التغيير لكلام الله تعالى، كما أنهُ يبحث في كيفية نطق ألفاظ القرآن الكريم(๕)، وقد يبحث أيضـاً في الأختلافات 
غبر المتو اترة(0) وقد عرَّف السيوطي علم القر اءات بأنهُ :((علم يعرف به كيفية النطق بالقرآن وبالقراعات مع

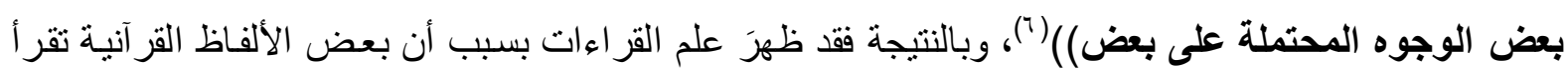

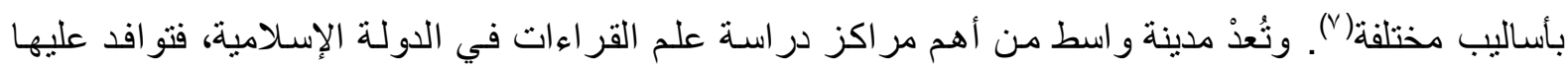
طلبة العلم من مختلف البلاد الإسلامية، وكان القرآن الكريم على قائمة المصـادر التي كان يحفظها طلابها، فضلاً عن در استهم لعلم القز اءات. أما أبرز العلماء الواسطيين الذين برعو العلم القر اءات فنذكر منهم:

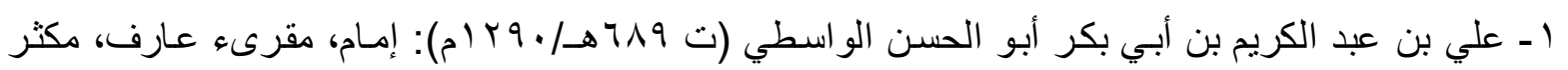

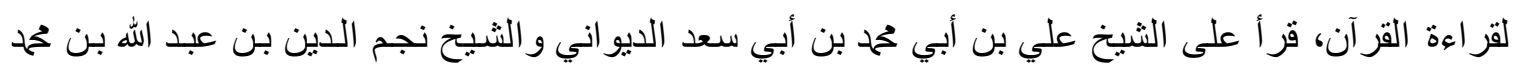
بن عبد المؤمن إلى أخرسورة الأنفال(^).

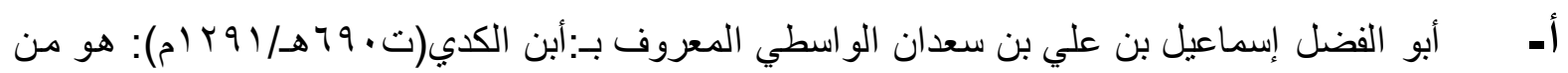

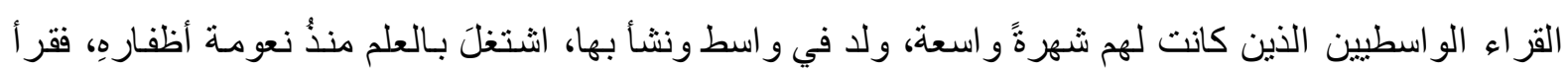
القر آن الكريم بـالقر اءات العشر على خالهِه أبي جعفر المبارك بن الفضل الواسطي (9)؛وبعدَ أن أنَ الثيخ أبو الفضل در استه للقر اءات القز آنية، انقطعَ للتدريس و التأليف في واسط حتى وفاتـهِ فيها، أمسا أهم إسـهاماته في هذا

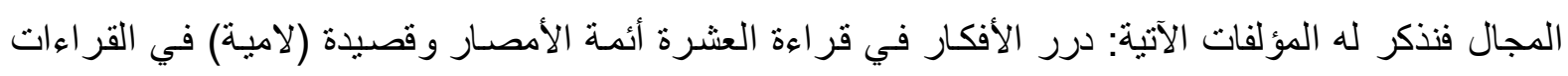
العشر وكنز المعاني في القزاءةِ، منهجهُ شبيه بمنهج كتاب(الإرشـاد) للمقرئ الو اسطي أبي العز القلانسي وقد

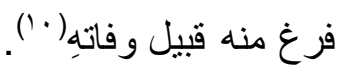

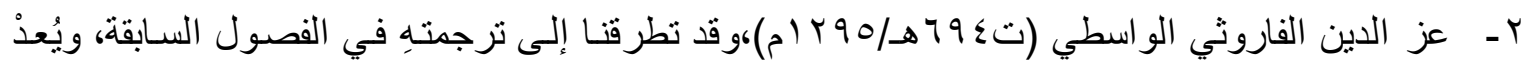
من المقرئين الذين كانت لهم شهرتهم الواسعة في مدينة واسط و المدن الإسلامية الأخرى، ولد في واسط عام

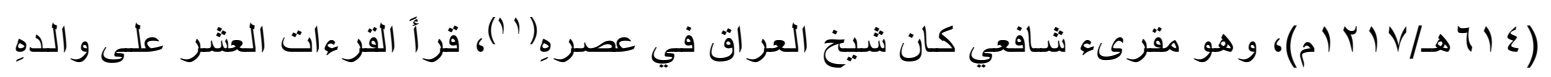
و على الحسين بن أبي الحسن بن ثابت الطيبي بالإرشادين،سمع الحروف من إبن مهر ان على الحافظ أبي عبد

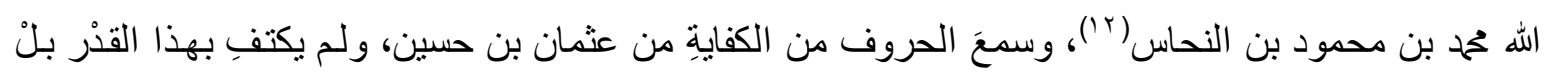

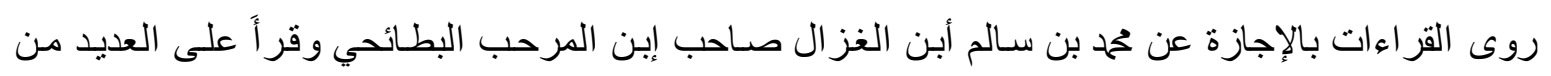
المقرئين في مدينةِ و اسط و المدن الإسلامية الأخرى.

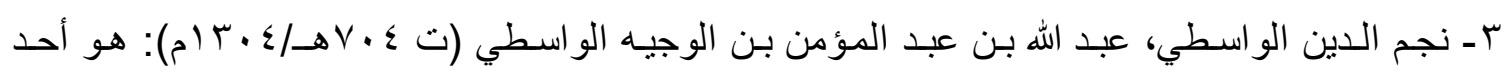

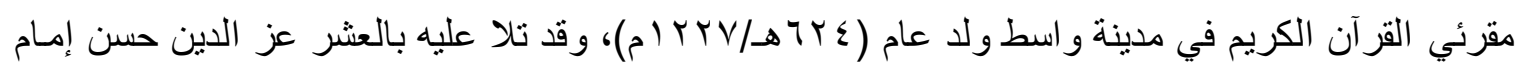
المدرسة المستنصرية وعبد المولى الواسطي بها، وبالبصـرة أحمد بن البرهـان عبد الرحمن و الثـيخ محهد

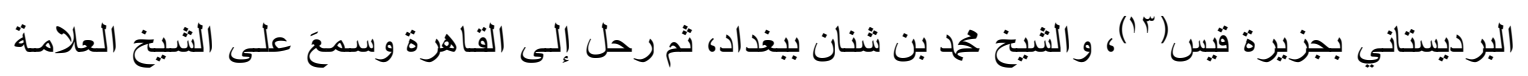
تقي الدين بن أبي عبد الله ححمد بن احمد بن الصايغ (ء) .) 


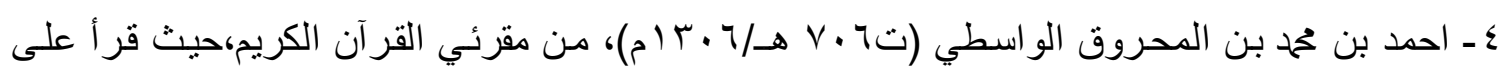

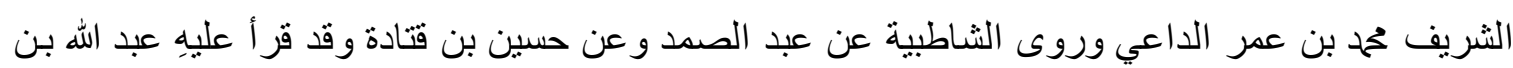
عبد المؤمن الو اسطي مؤلف الكنز (10).

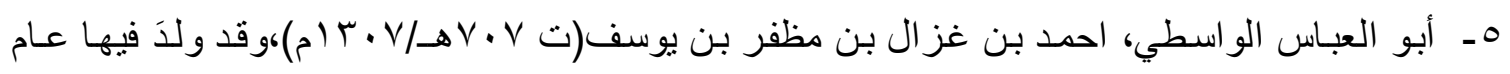

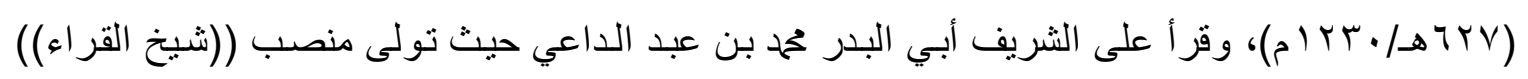

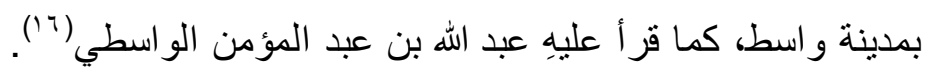

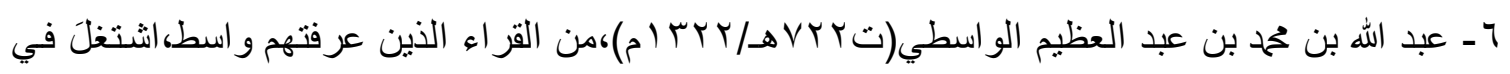
علم القراءات حيث قر أ بو اسط على الثيخ خريم،و على حسن الكوسـاني و احمد ومحمد أمبن غز ال و غير هم، كذلك رحلَ إلى دمشق وجلس للإفادة ونظم قر اءة يعقوب في كر اسة (IV').

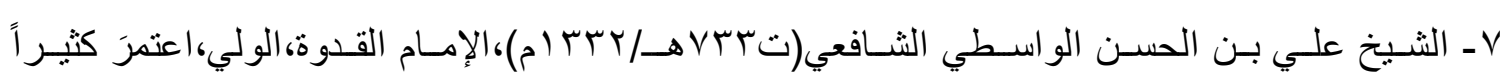
وقدُعرفت بأنهُ: مقرىء للقر آن الكريم حيث تلا أكثر من أربعة آلاف ختمة وقد مات ببدر محرماً(^ا').

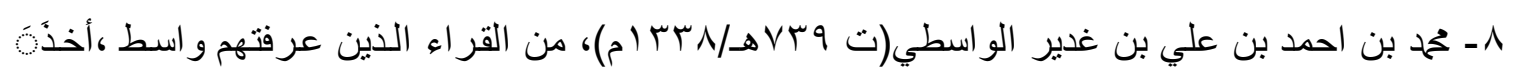
القراءات عن عز الدين الفاروثي وصحبهُ وجاور بمكة وسمع من عبد الله بن مروان الفارقي، وكان مـاهر اً

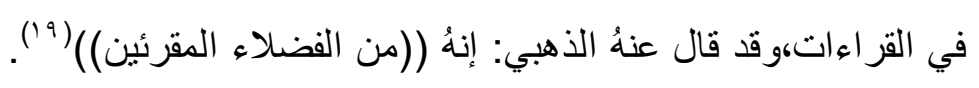

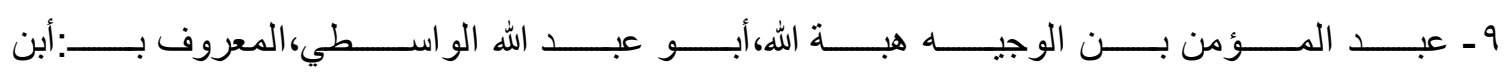

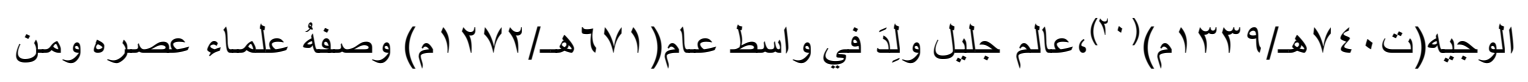
بعدهم من القر اء بصفات تدل على شأنه في علم القراءات فقال الذهبي ((كان بصير اً بهذا الثـأن نظم في العشرة))، وقد عرف عنهُ انهُ(شيخ العر اق في زمانه) (؛). أما أهم إسهاماته في علم القراءات فهي: تحفة

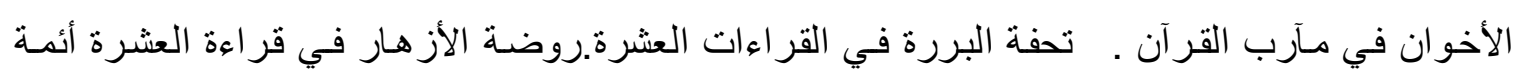
الأمصار و هي قصيدة عدتها(ألف ومائة وثلاثة وخمسون بيتاً). و الكنز في القر اءات العشر جمع فيه بين

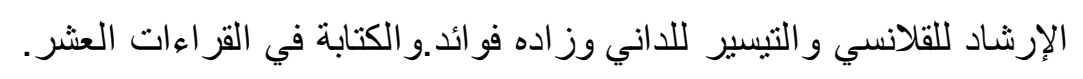

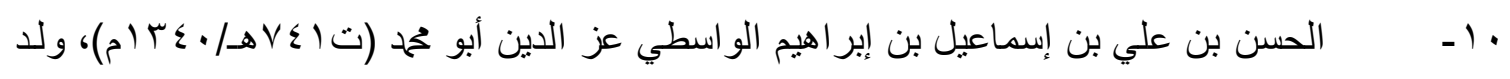

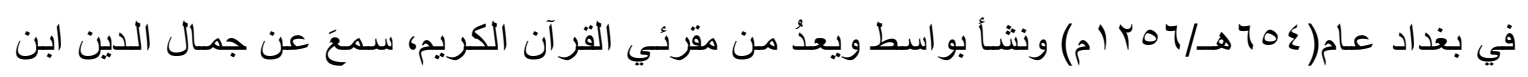
النقيب بعض تقسيره الكبير وناب في الإمامة بالمسجد النبوي( (r).

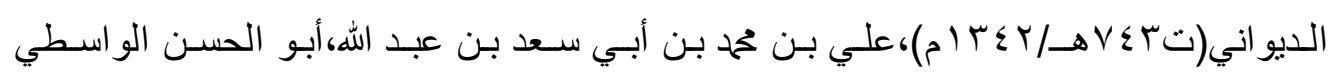
$-11$

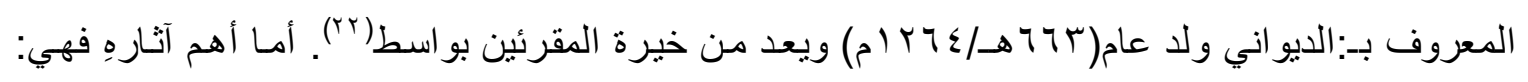
روضة التقرير في الخلق بين الإرشاد والتيسير، كذلك له قصيدتان في القراءات وشرحهما. r ا - أحمد بن الحسين المالحاني، توفى في القرن الثامن الهجري/الرابع عشر المبلادي وقد سماه

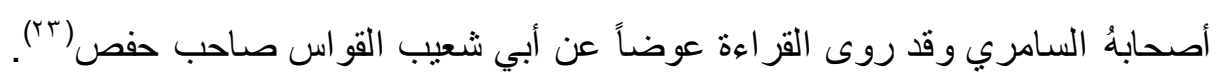




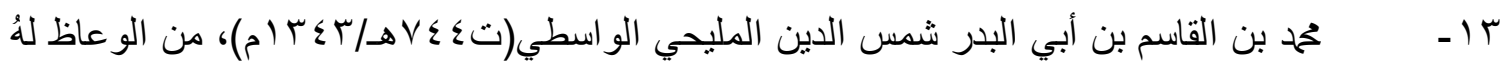

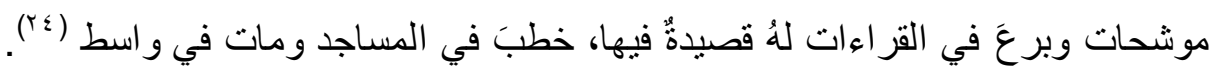

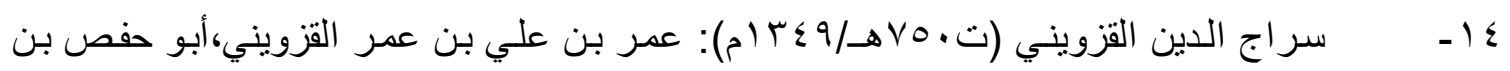

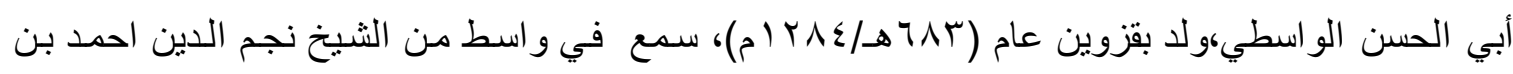

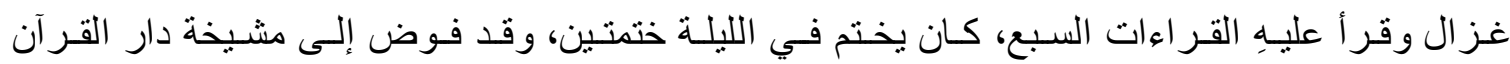
بـ:البشيرية(ان).

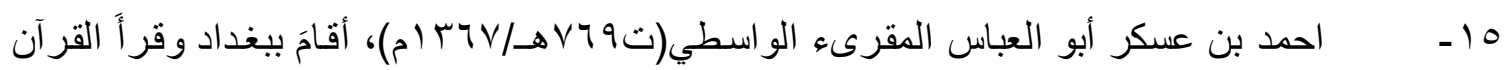
على جمعة الواسطي وقد سمع صحيح مسلم من أحمد بن غز ال، توفى عن نحو ثمانين سنة(ب0).

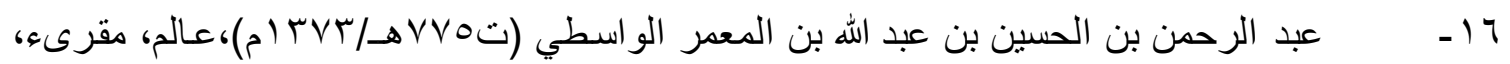
من شيوخ الثـافعية، قرأ العشر على نجم عبد الله بن عبد المؤمن و الإرشاد على يحيى بن عبد الله الواسطي

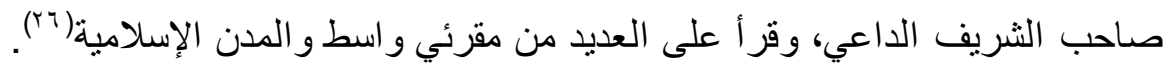

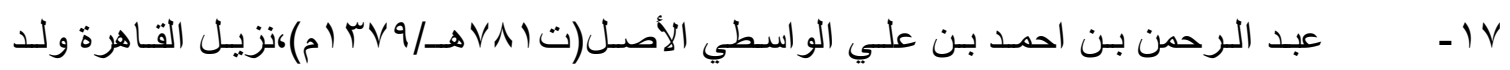

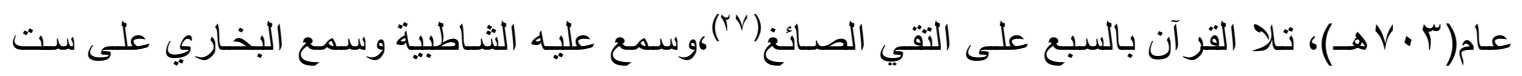

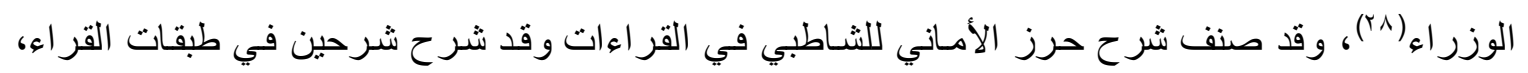
كذلك نظم غاية الإحسان لأستاذه أبي حيان(ra').

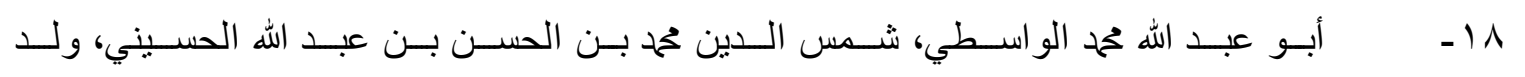
عام(V) V V/ V I I ام)،و يعدُ من القر اء الو اسطيين وقد درس بالصـار مية وكتب الكثير نسخاً وتصنيفاً بخطهِ

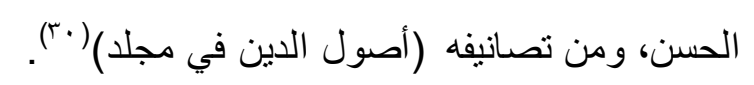

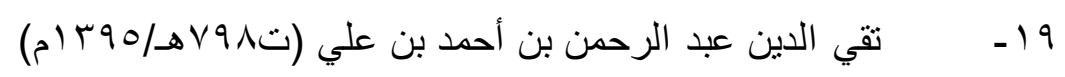
من الواسطيين الذين عرفو ا بعلومهم ومعرفتهم في المدن الإسلامية الأخرى، عرف بإبن الواسطي و أبن

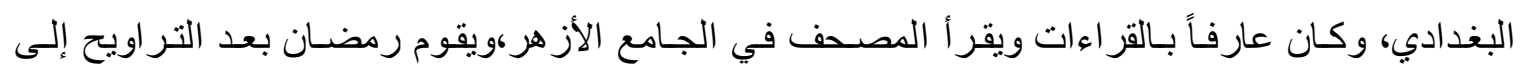

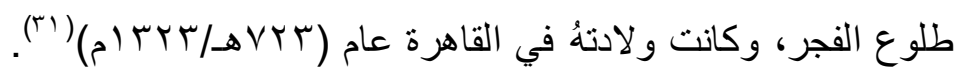

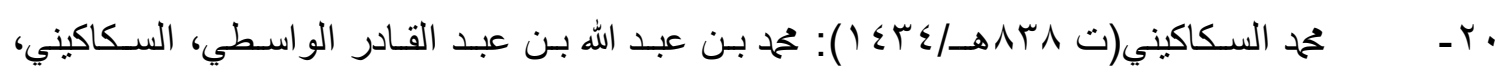
الثافعي، مقرىء وققيه، نوفى بمكة أهم أثنارِِ في علوم القر آن (نظم بقية القراءات العشر وتكملة الثـاطبي)

اكتفينا بهذا العدد من المقرئين الواسطيين، إذ يوجد عدد هائل منهم في طيات المصـادر ولاسيما كتب التر اجم و إن وجود مثل هذه الكوكبة الرائعة من القراء في مدينـة واسط مـا هو إلا دليل على أن و اسط هي بحق كمـا ذكرت المصادر مدينة (القر اءو المقرئين)، و أنها قد صـارت قبلة للطلبةِ و العلمـاء الذين جاءوا من جميع المدن إن 
الإسلامية ودرسو ا علم القراءات العشر و السبع ومنهم من بقي في و اسط والبعض منهم ارتحل إلى بلاده لينشر علمه، ولم يكتفِ طلبة العلم فقط بدر اسة علم القراءات و البحث في علومه بل قامو ا بتأليف العديد من الكتب في وني هذا المضمار.

\section{ثانيك-علم التفسير}

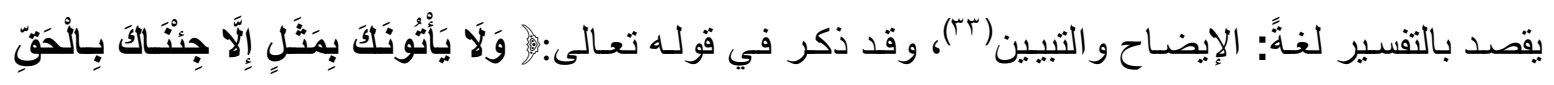

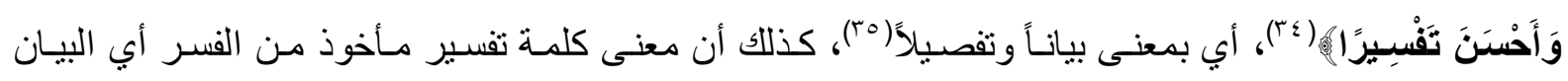

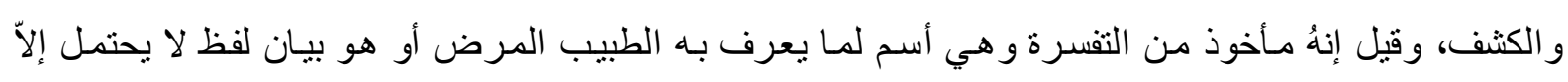

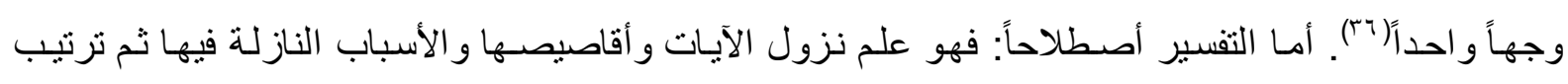

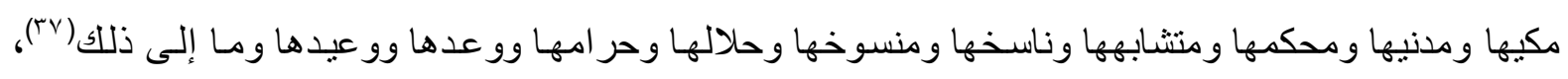
أي بمعنى آخر هو العلم الذي يبحث عن كيفية النطق بألفاظ القر آن ومدلو لاتها وأحكامها الأفر ادية و التركيبية ومعانيها التي تحمل عليها التركيب(^)". وعُرِفت التفسير أيضاً((انه علم يفهم به كتاب الله تعالى المنزل على نبيه

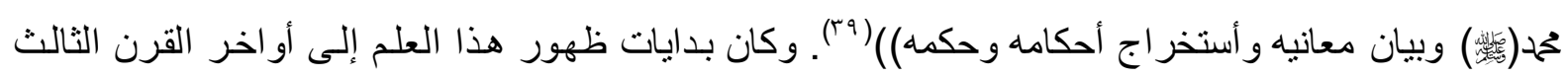
الهجري/ التاسع الميلادي،أما سبب ظهور هذا العلم في تلك المدة الزمنية فلأن المسلمين في عصر الرسالة لـ لم

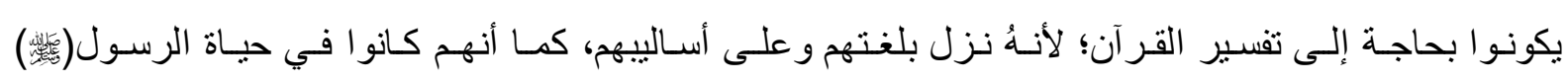

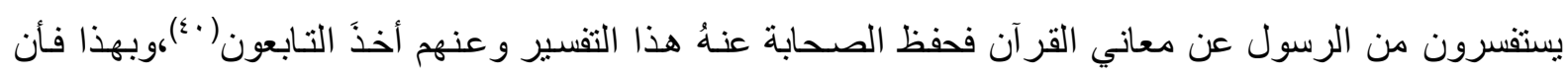
التفسير من أقدم العلوم صلة بالتشريع الإسـامي،و لابد من الإشـارة هنـا إلى ظهور اتجاهين في التفسير؛الأول، التفسير النقلي المسند إلى الآثار المنقولة عن السلف و هي معرفة الناسخ و المنسوخ و أسباب النزول وقاصد الآيـة وكل ذلك لا يعرف إلا بالنقل عن الصحابة والتابعين؛ وسمي كذلك بـ:المنقول أو بالرو اية وهو تقسير القرآن بنصه وتفاسير الرسول(筷) و الصحابة و التابعين وتابعي التابعين(1)، أما الثاني فهو التفسير بـالر أي أو بالاجتهاد

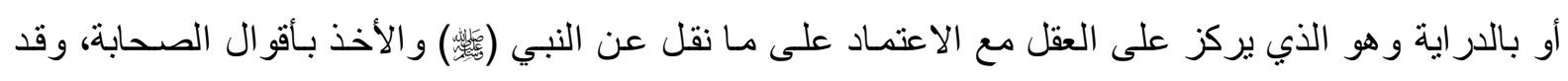
عرف عن الواسطيين تعلقهم بعلوم القر آن وتدريسه ومن تلك العلوم علم التفسير ومن أبرز علمـاء التفسير في واسط:

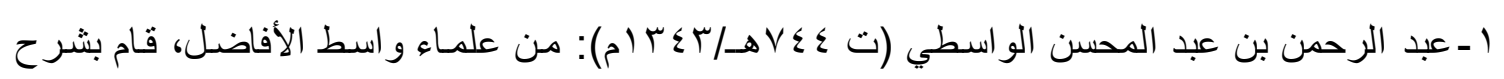

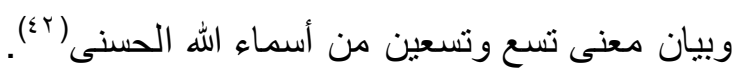

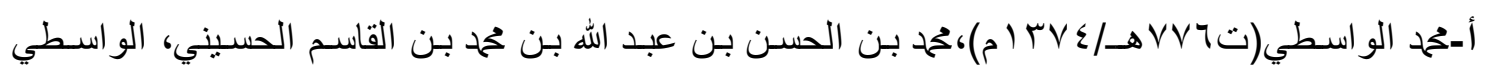

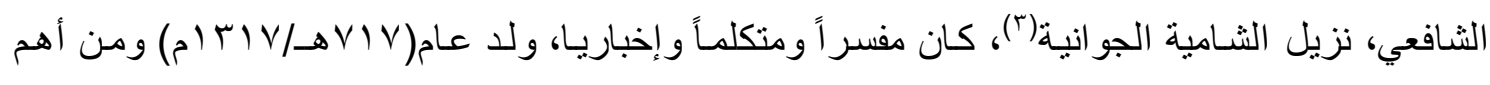
تصانيفه في علم التقسير: كتاب أصول الدين. تقسير كبير شرح فيه كتاب منتهى السؤال والأمل في علمي الأصول والجدل في ثثلاث مجلدات . 


\section{ثالثك- علم الناسخ والمنسوة}

معناه رفع حكم و اثبات حكم، كذللك يطلق على معـان تدور بين النقل و الإبطسال و الإز الة|(؛)وهو من العلوم المهمة، إذ لا يجوز لأحد أن يفسر القر آن إلاّ بعد أن يعرف منه الناسخ و المنسوخ. ومن أنشهر العلمـاء الذين أبدعو ا في هذا العلم :

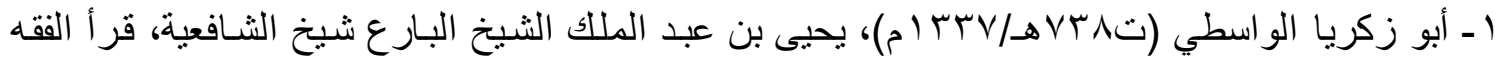
وبرعَ فيه، وكان فقيه العر اق في زمانه تققه عليه شمس الدين تحمد بن القاسم الملحي الو اعظو وغيرِهِ ومن

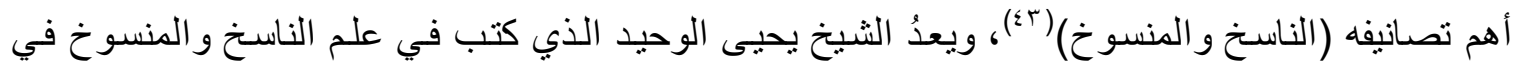
العهد المغولي.

\section{رابعك- علم المديث}

هو المصدر الثاني للتشريع الإسـامي بعد القرآن الكريم، وهو أصدق شـيء بعد القرآن الكريم وقد

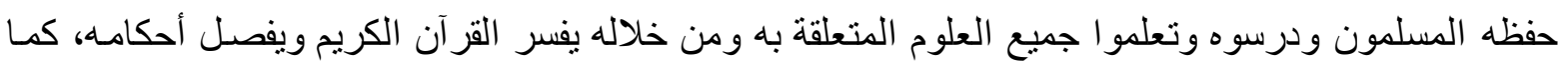
أن علم الحديث هو أكثر العلوم الدينية شيوعاً لان الثريعة تؤخذ من الكتاب و السنة،ليتم اخذ الدين عن أصول

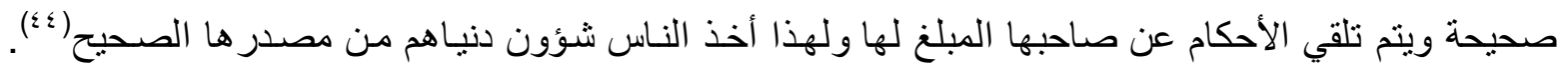

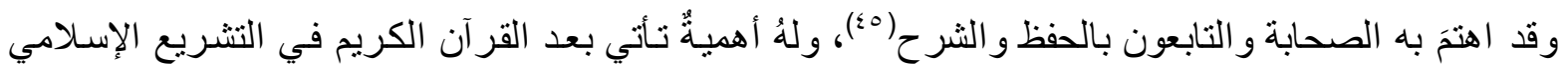

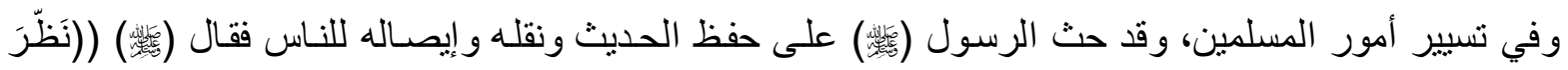

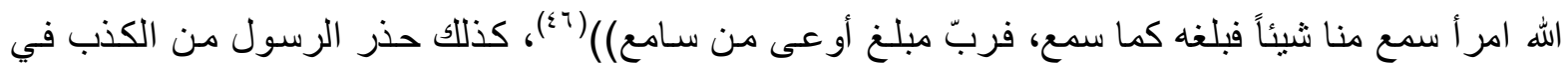

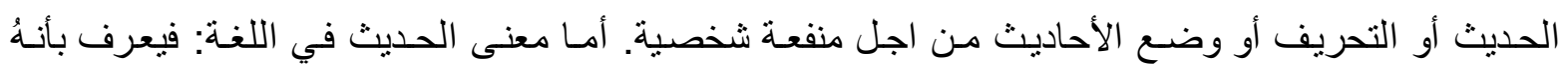
مأخوذ من حدث حدوثاً وحداثة نقيض القديم، والحديث اسم من التحديث أي الأخبار (₹)؛؛ أمـا أصطلاحاً: فهو

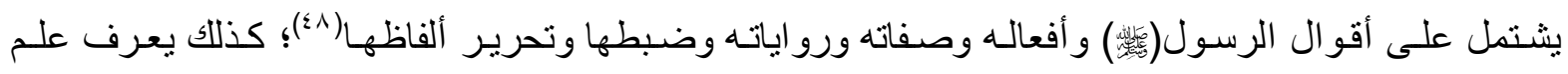

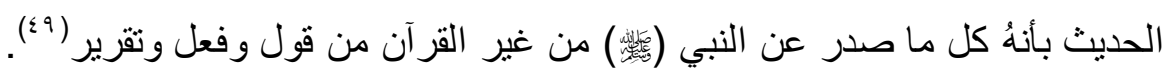

وقد عُرِتَّ بأنهُ :((مدار العلماء الأعلام في استتباط قواعد الأحكام، ليبان الحلال والحرام ،وكيف لا يكون كذلك، ومصدره عمن لا ينطق عن الهوى إن هوإلا وحي يوحى))( •)، أمسا الخطيب البغدادي فقال((أنـُ

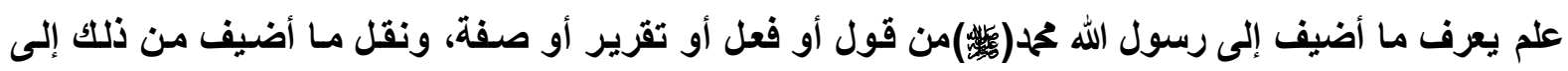

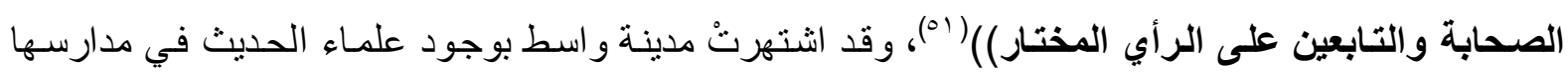
وجو امعها ودور العلم فيها و اختلفتنْ طبقاتهم و ألقابهم فمـنهم مـن تلقب بالحسافظ وهو العـارف بسـن الرسـول

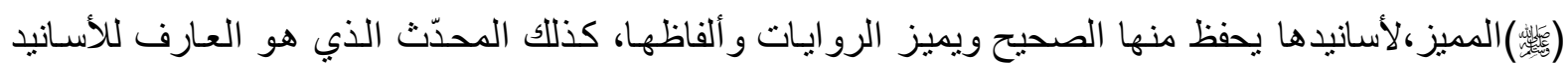
و العلل و أسماء الرجال وحفظ جملة من المتون، وان علم الحديث من العلوم التي يتوقف عليها الاجتهاد الفقهي ويقوم عليه أستنباط الأحكام الثرعية من مصادر ها.

وقد عرف عن أهل و اسط رو ايتهم للحديث المسند، ويقصد بالمسند((الذي يروي الحديث بإسناده سواءً

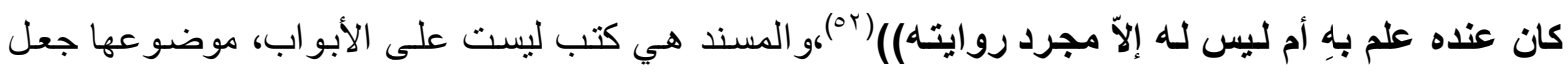


حديث كل صـحابي على حدة صحيحاً كـان أم حسناً أم ضـعيفاً، مرتبـاً على وفق حـروف الهجاء أو القبائـل أو السـابقة في الإسـام وغير ذلك، وقد يطلق المسند عند بعض المحدثين على كتاب مرتب على الأبواب أو

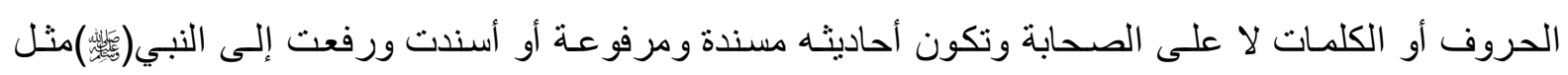

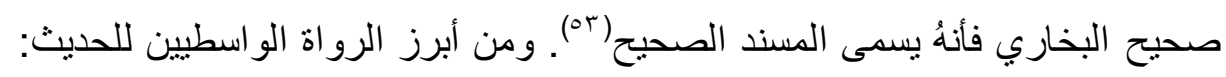

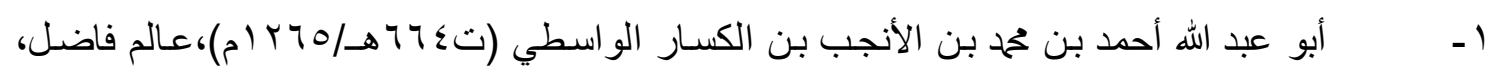

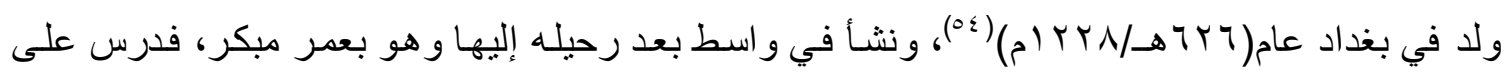

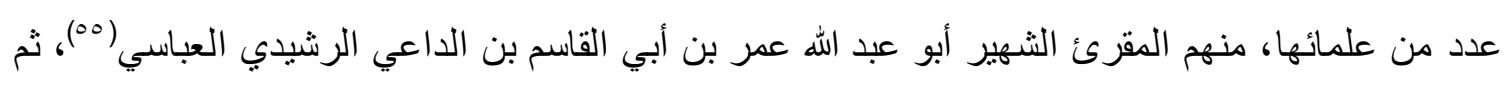
رحل بعد ذلك إلى بغداد فدرس هناك الفقه الحنبلي فضلاً عن الحديث حنى أصبح فقيهاً، حافظاً ومحدثاً لـه

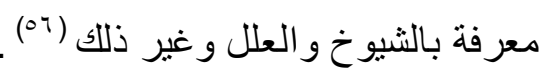

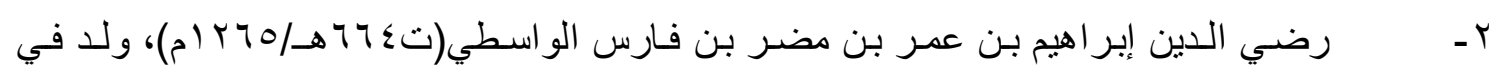

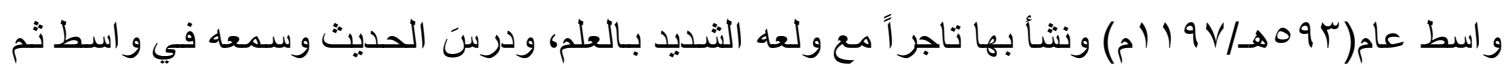

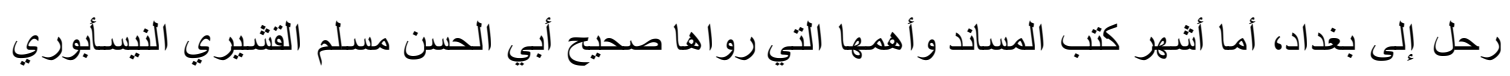

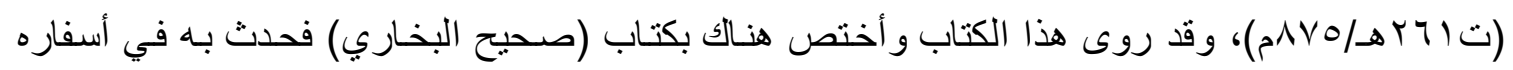

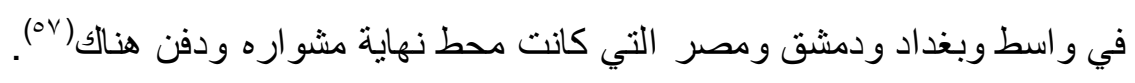
بـ - إبر اهيم بن علي بن احمد بن فضل الواسطي، الدمشقي، الصالحي الملقب تقي الدين الحنبلي الز اهد العابد،

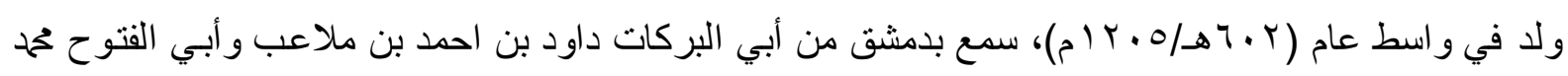

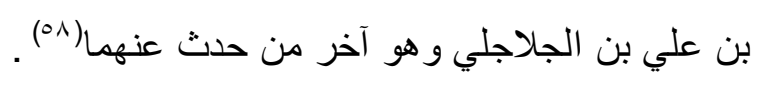

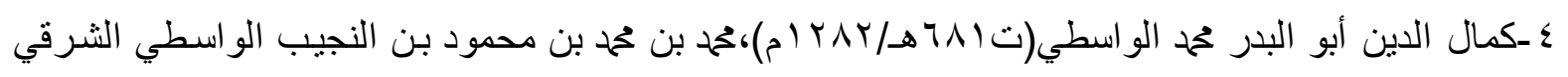

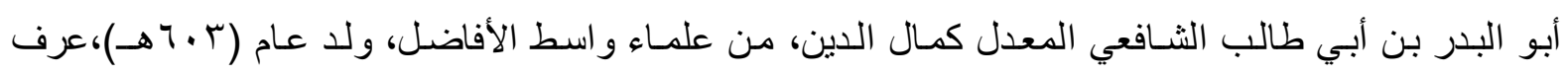
بالثيخ الفقيه المحدث، وسمعَ من أبي بكر حمح بن مسعود بن بهروز ومن أبي بكر حمحد بن سعيد بن الموفق

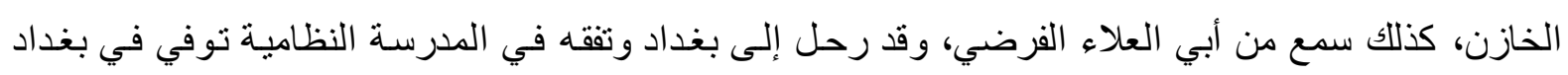

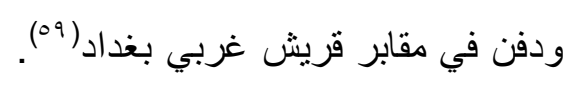

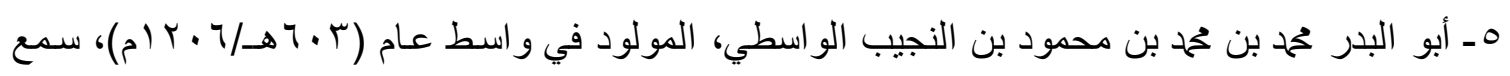

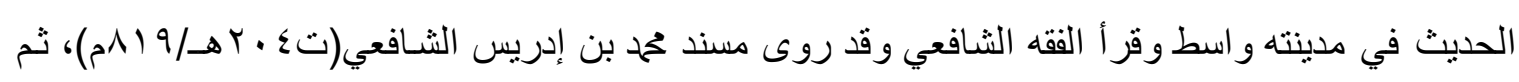

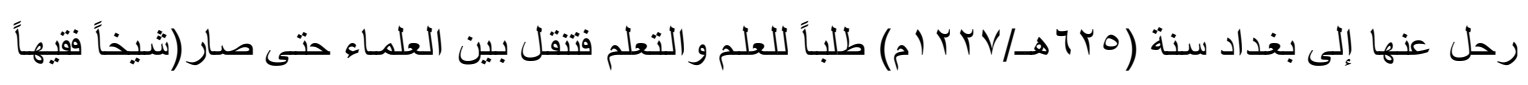

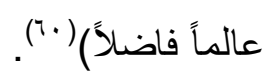
1 - أبو محمود أبو الفضل بن أبي العباس المنعوت بـالعز الواسطي سبط الثيخ ححمد الركابدار المعروف

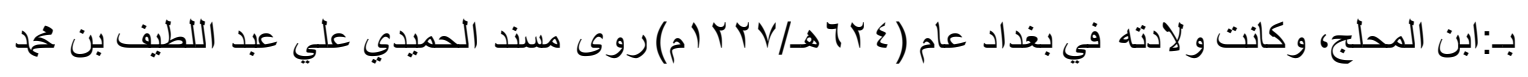

بن القبيطي، وأبي العلاء الفرضي، وممن حدث في هذا المسند عبد الرحمن بن احمد بن أبي غالب( (ل). 


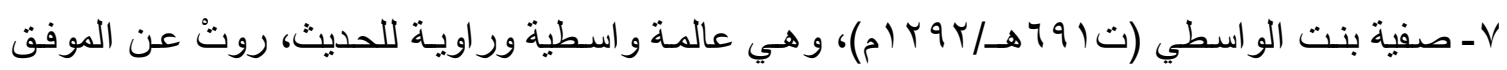

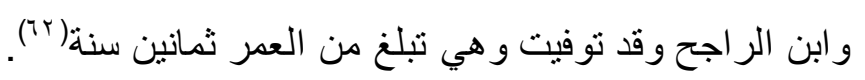

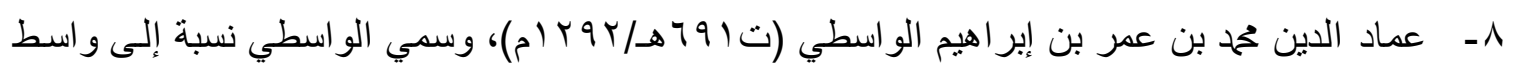

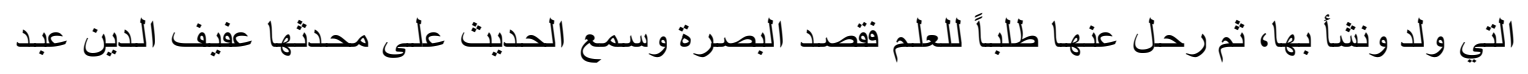

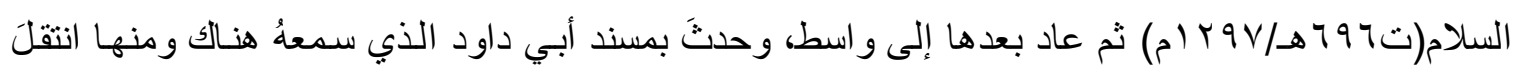
إلى بغداد التي سكنها حتى وفاته (r).

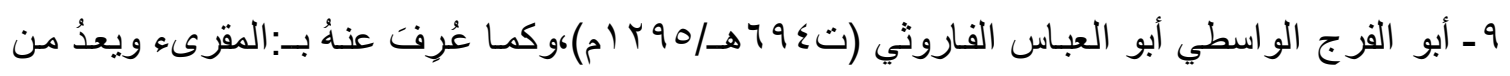
المحدثين الذين عرفوا في مدينة واسط، وقد روى(صحيح البخاري)، بمدينته وفي بغداد ودمثن التي سكنها

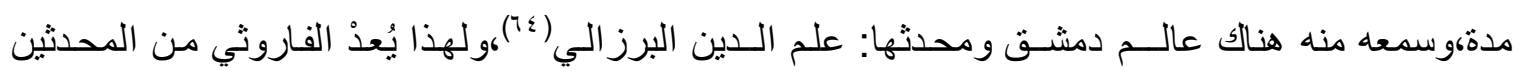
الأو ائل(70)، كما أنهُ روى(مسند الثافعي) في دمشق بعد أن سمعه في و اسط (ب7").

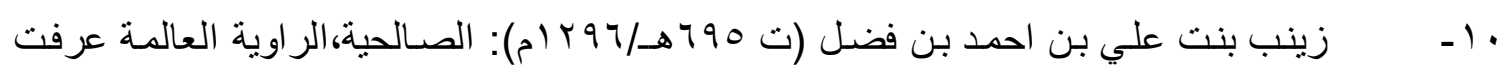

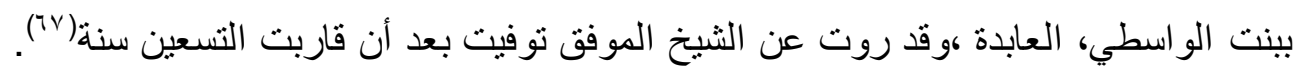

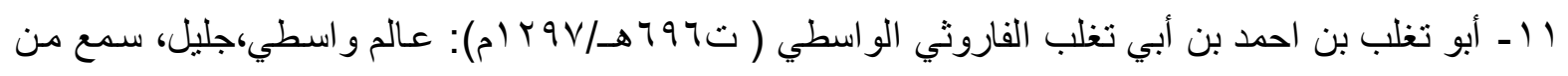
ابن الزبيدي و غيره وتوفي في دمشق ولهُ إحدى وتسعون سنة(7^).

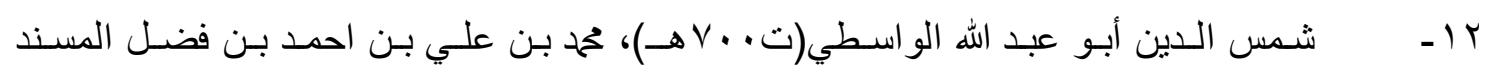

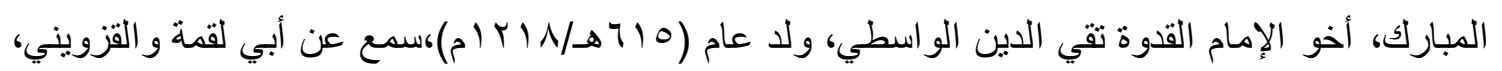

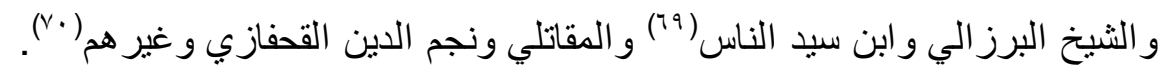

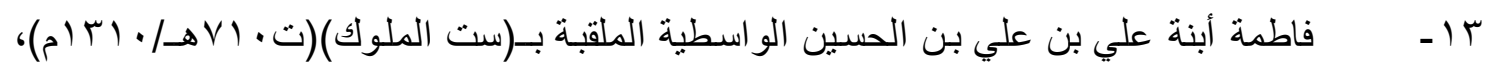
إبنة أبي نصر الحنبلية واسطية الأصل عرفت بأنها شيخة جليلة عفيفة زاهدة سمعت من أبي بكر محمود

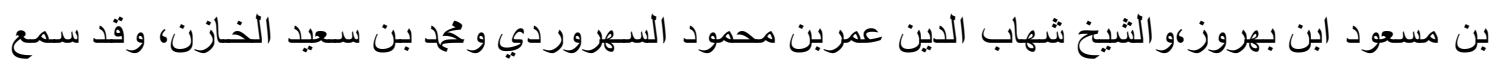
منها أبو عبد الله ححمد بن عبد الرحمن بن شـامة والإمـام تـاج الدين أبو الحسن علي بن سنجر بن السباك و الثيخ سر اج الدين بن عمر القزويني، توفيت في بغداد ودفنت بمقبرة احمد بن حنبل ( (v).

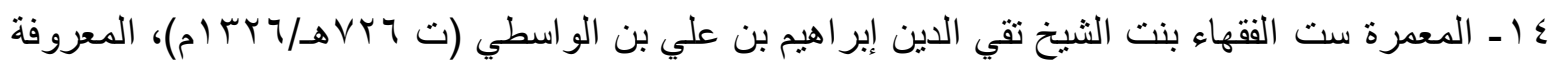
بالصالحية، المحدثة، سمعت جزء ابن عرفة من عبد الحق حضور اً وسمعت من إبراهيم بن خليل و غيره و أجاز لها جعفر الهمذاني، واحمد بن المعز و ابن القسطي و عدد كثير وكانت مشـاركة صسالحة مباركة، عرفت بأنها

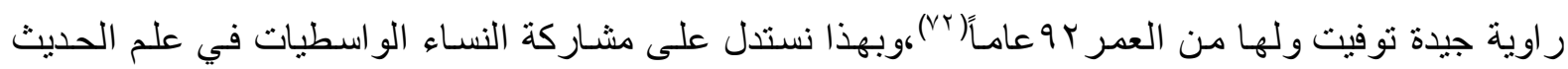
النبوي الثريف. 


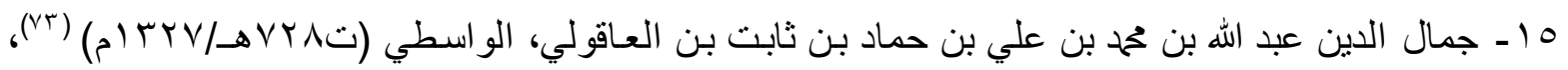
الذي يعدُ من العلماء الأجلاء الذين برزوا واشتهروا في العلوم الدينية، كان محدثاً لامعاً سمع من جماعة من بن

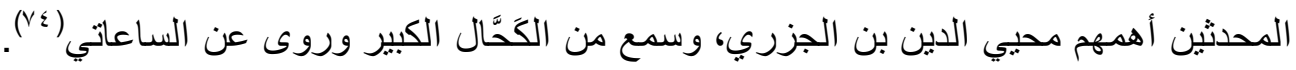

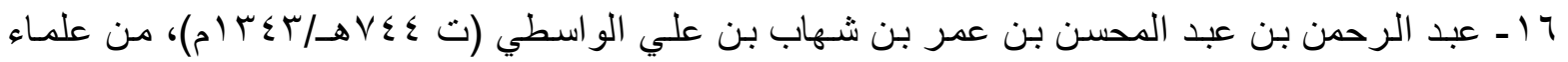
و اسط الأفاضل، عرف ب-الثافعي و عرف محدثاً رحل إلى دمثق وحدث بها وسمع من العديد من المحدثين، ولهُ كتاب ((اللؤلؤة في الحديث)(ب0)

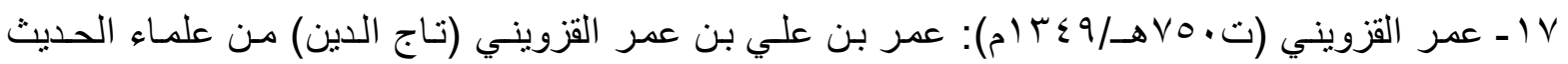
الو اسطيين، عرف بأنهُ حافظ ومحدث من أهل العر اق، وقد حدث كثير اً وسمعَ من أبي عبد الله محد بن عبد الله بن أبي القاسم صحيح البخاري، كذللك سمع صحيح مسلم وسمع من ست الملوك بنت علي بن علي بن البدر، ولد

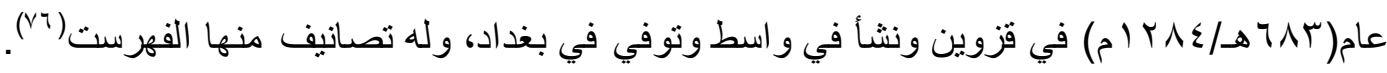

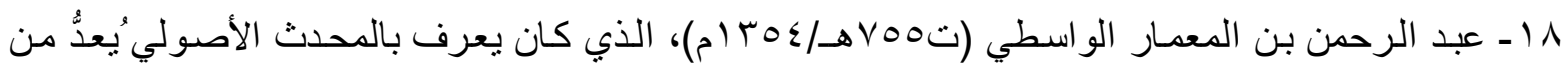
علماء الحديث البارزين في مدينة واسطومن أهم إسهاماته: تحفة ذوي الرشد في الأحاديث الثنائية السند(vv). 9 ا ـ عبد الرحمن بن الحسين عبد الله بن الحسن بن عبد الله بن نصر بن المعدر عبد الدايم بن المعمر بن

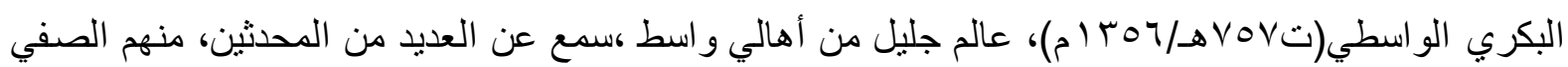
عبد المؤمن و ابن تبع، وابن الخباز، و وعرف بـ:الفقيه،حيث تفقه بالثافعي( (V^).

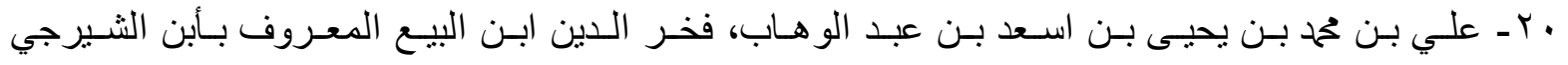

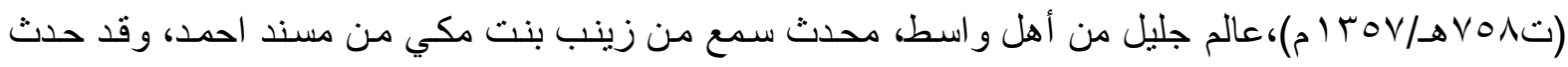

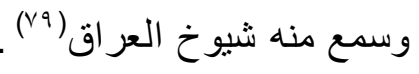

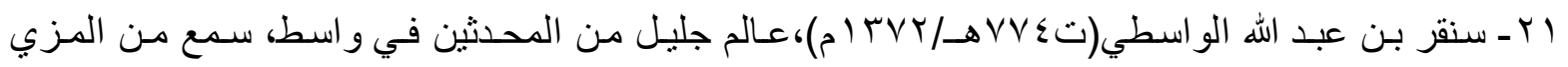

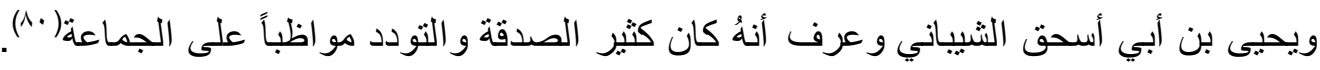
بr - غياث الدين أبو المكارم محمد بن صدر الدين ححمد بن فخر الدين،عبد الله بن أبي الفضل محمد بن علي بن حماد

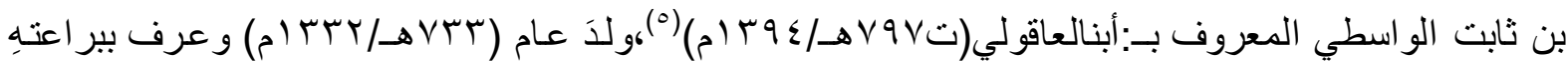
في الحديث و المعاني و البيـان وقد ألف في الحديث و الفقه والتاريخ ومن مؤلفاته: الدراية في معرفة الرواية. و الرصف لما روي عن النبي من الفعل و الوصف. وشرح مصابيح البغوي. وشرح منهاج البيضاوي.

\section{خامساك- علم النققه}

الققه في اللغة: الفهم و العلم بالثيء، و الفهم له وغلب على علم الدين لسيادته وشرفه وفضله على سـائر أنواع العلوم(1). وفي الاصطلاح: هو العلم الباحث عن الأحكام الشرعية الفرعية العملية من حيث استتباطها

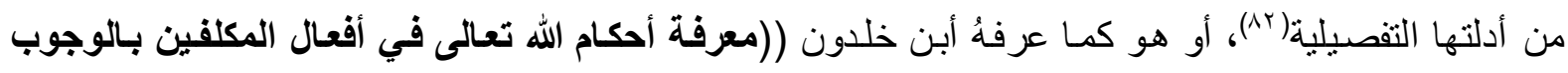
والحظر والندب والكراهة والإباحة وهي منتقاة من الكتاب والسنّة وما نصبه الشارع لمعرفتها من الأدلة، فِإذا 
استخرجت الأحكام من تلك الأدلة قيل لها فقه)(r(A). ولعلم الفقه مكانة سامية وأهمينٌة كبيرة؛ لكونـهُ علمـاً يختص

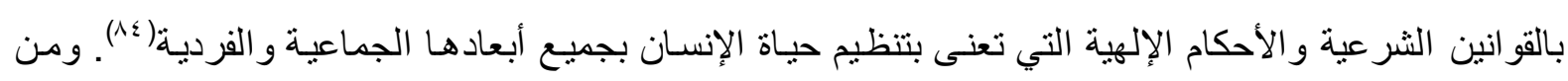

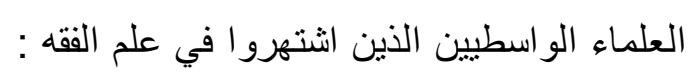

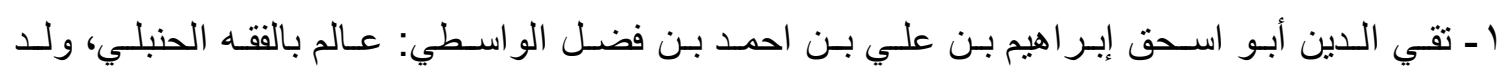

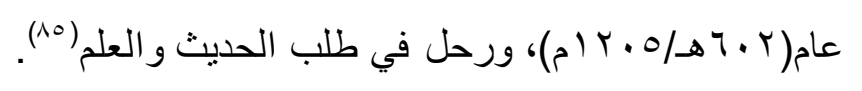

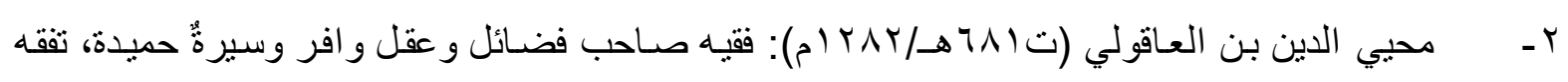

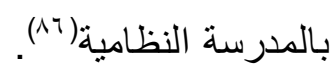

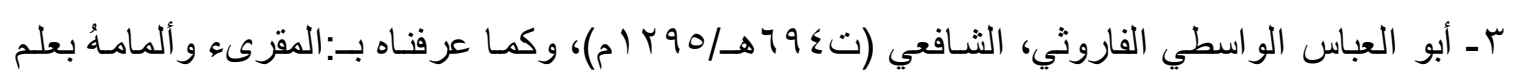

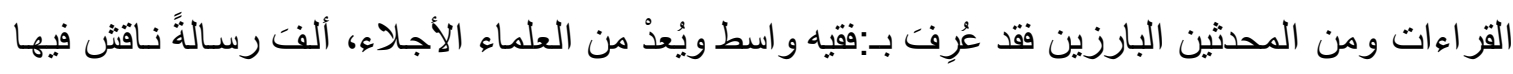
مسألة السماع، و قد اشتملت الرسالة على فصول حاصل كلامه أنها بدعة ظهرت بعد المـائتين ببغداد وقد تكلم فيها الثافعي و أنكرَ عليهم في هذا العصر حيث وقع بين الثافعية وغير هم من المذاهب الإسـامية من مناظر ات وصر اعات وفتن (^v).

أـ عمـاد الدين أبو العبـاس احمد بن إبر اهيم بن عبد الرحمن بـن مسـود الواسطي الحزامسي

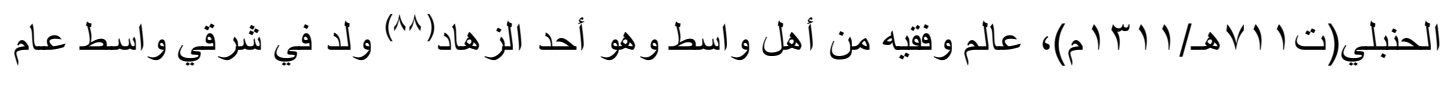

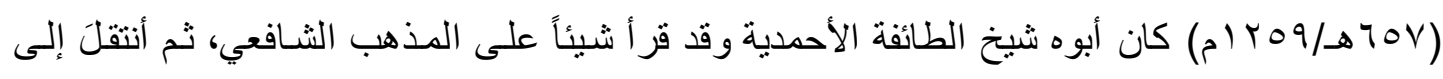
المذهب الحنبلي وخالط طو ائف الفقهاء وكتب الحديث والسنة و الآثار توفي بدمشق ودفن بسفح جبل

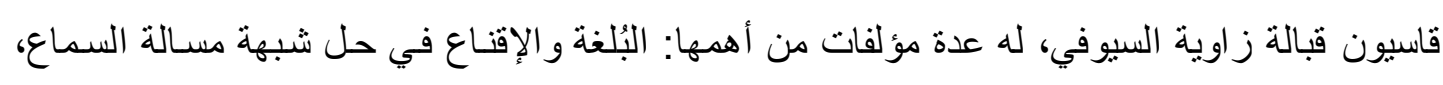
ويعدُّ هذا الكتاب من الكتب الفقهية المهمة ألفه بدمشق، ولهُ مؤلفات أخرى في الفقه الحنبلي.

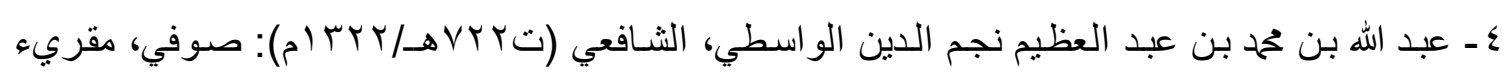

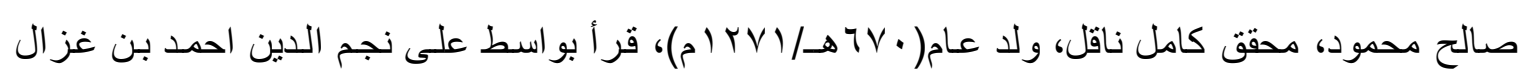

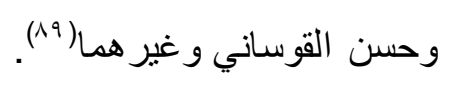

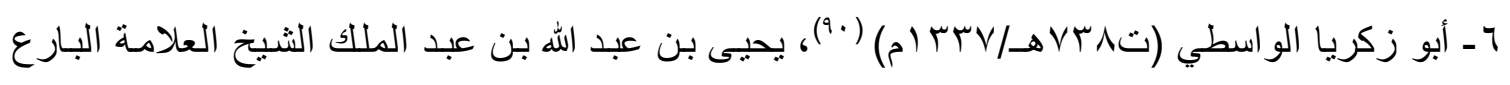

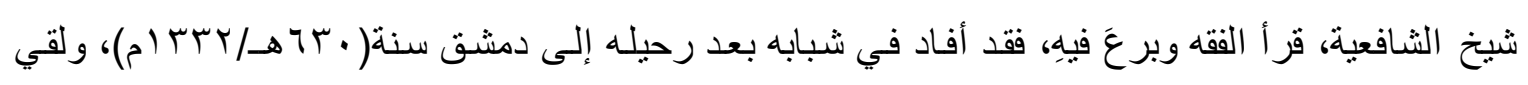

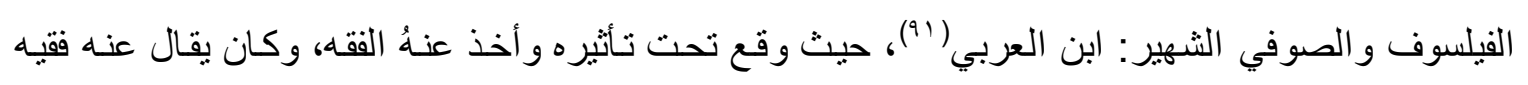

العر اق في زمانه تققه عليه ابن عبد المحسن وشمس الدين محمد بن القاسم الملحي الو اعظ وغير هما.

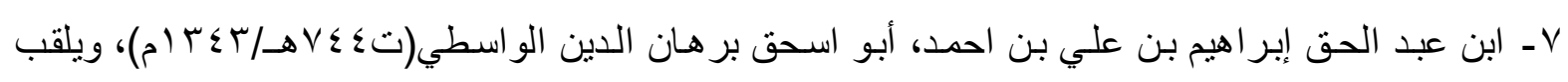

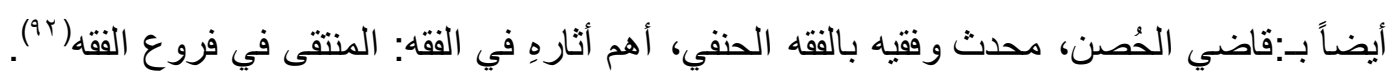

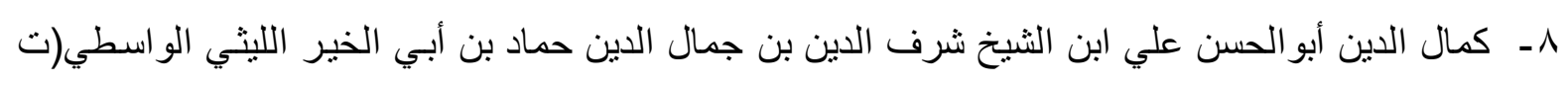

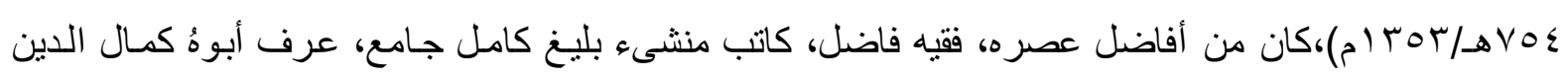

\section{-rqr.}


بأنهُ من مشاهير الفقهاء(بهو)، ألف عدة مؤلفات نذكر منها: الأزهار في الرسائل و الأشعار والرسائل في منون البديع.

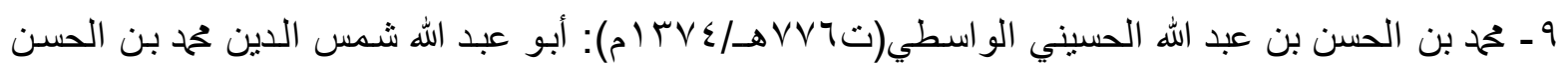
بن عبد الله الو اسطي،عالم جليل كان مفسراً عالماً بأصول الفقه، أحد شيوخ الشافعية البارعين في الفقه و الأصول ومتكلماً وإخباريا(؟9)، من أهم إسهاماته في الفقه(90): تفسير كبير .والرد على على التناقض للأسنوي.

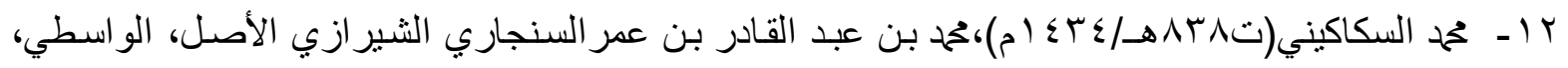

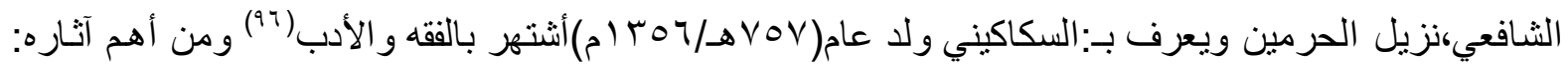
شرح المنهاج البيضاوي وتخميس البردة،سماه تنفيس الثدة وبلوغ المر اد في تخميس بانت سعاد وقصيدة من نحو أربعين بيتاً فيما وقع من النهب بالمدينة المنورة.

\section{سادسك- التمصفوف}

التصوف كما عرفهُ أبن خلدون((من العلوم الثرعية الحادثة في الملة، واصله أن طريقة هؤلاء القوم لم تزل عند سلف الأمة وكبارها من الصحابة والتابعين ومن بعدهم طريقة الحق والهداية، وهو العكوف على العبادة والأنقطاع إلى الله تعالى والإعر اض عن زخرف الانيا وزينتها والزهد فيمـا يقبل عليه الجمهور من لذةٍ

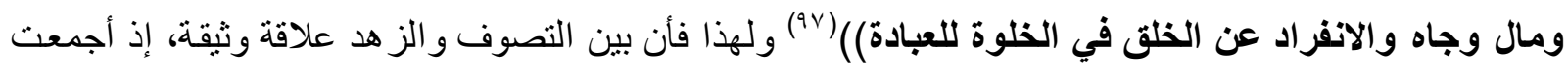
الآر اء على إن أصل كلمة (التصوف) يرتبط في حقيقته بالز هد ونبذ الدنيا كنسبتهم مثنا إلى أهل (الصفة) أو إنهم

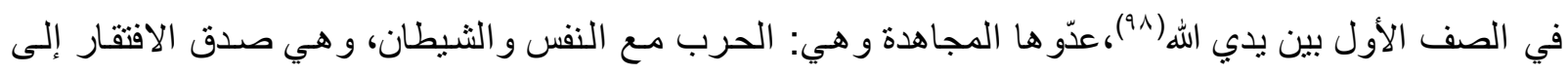
الله تعالى بالانقطاع على كل ما سو اه، كما أن التصوف يعّد مظهر اً من مظاهر الفكر الإسلامي، وقد أصبح هذا الفكر عند بعض المتصوفة علماً ينفرد به طبقة خاصة منه، كما أتخذَ شكلاً فلسفياً نـادى بـه بعض فلاسفة الإسـلام

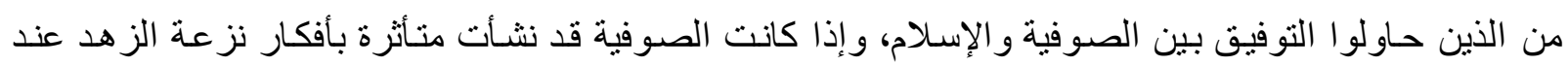

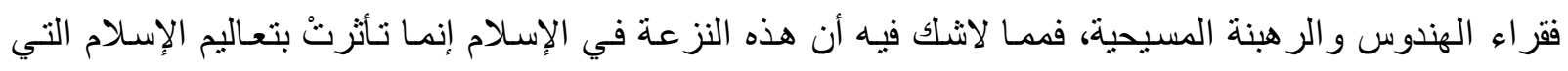

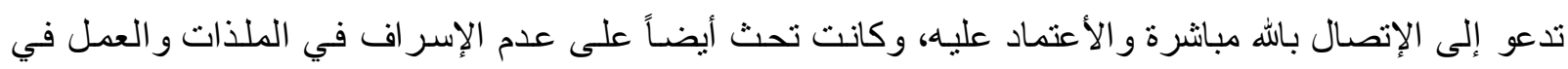

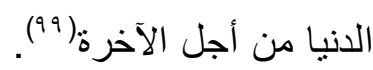

و التصوف كما يقول المنصوفة:((هو بغضك الدنيا حباً في الله)) أو هو موتك في نفسك كي تحيا في الله، أو هو ألا تملك شيئاً ولا عليك شيء(.')، وباختصـار هو طريق الوصول إلى الله تعالى،ويطلق المتصوفة على هذا

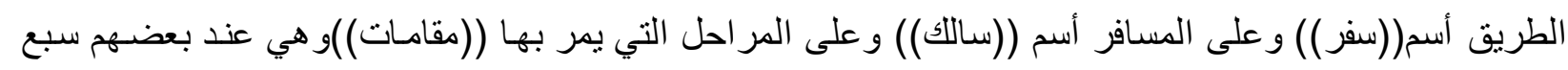

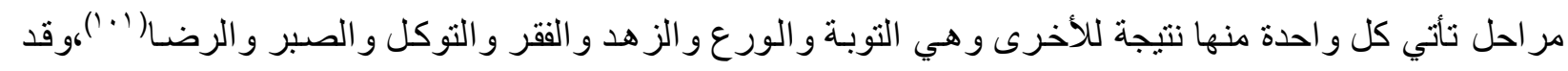

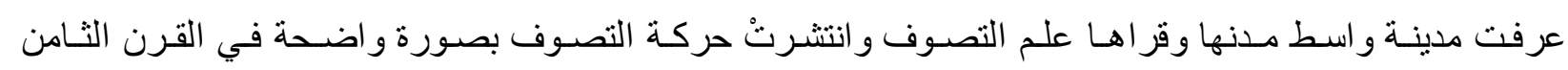
الهجري/الر ابع عثر الميلادي، حيث كانت واسط، حالها مثل حال المدن الإسلامية الأخرى التي ظهر فيها التصوف

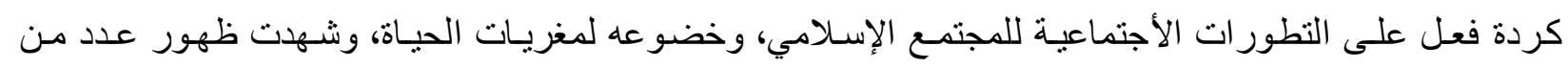

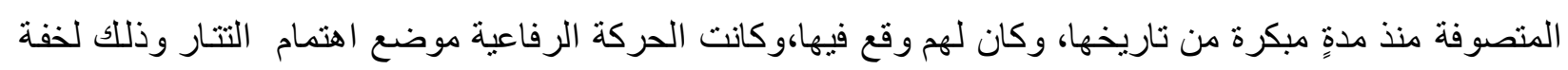


يدهم ولسير هم على النارو أكلهم للحيات، حيث كرمَ التتارشيوخ الرفاعية ومنهم صـالح بن عبد الله البطائحي وذلك

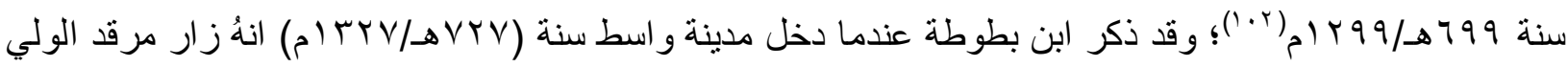
أبي العباس احمد الرفاعي الواقع في قرية أم عبيدة حيث أنتشرتْ الطريقة الرفاعية فيها بعد أن أستقرتْ أسسها في

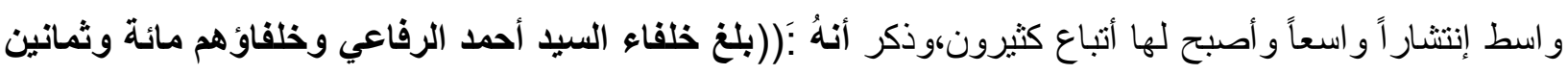
ألفاً حسال حياته ولم يكن في بلاد المسلمين المعمورة مدينة أو بليدة أو قطر تخلو ربوعه من زوايـاه ومحبيـه

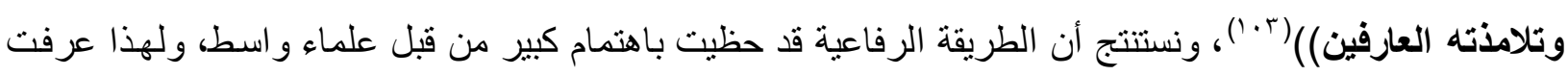
الطريقة الصوفية بـ((طريق دين بلا بدعة وعمل بلا كسل ونية بلا فساد وصدق بلا كذب وحال بلا رياء ومقام بلا

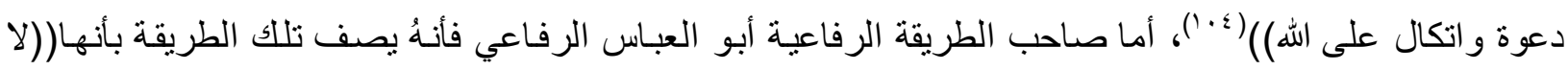
تورث عن الأب و الجد و إنما هي طريقة العمل و الجد والوقوف عند الحد، وذرف الدموع على الخد، و الأدب مـع الله

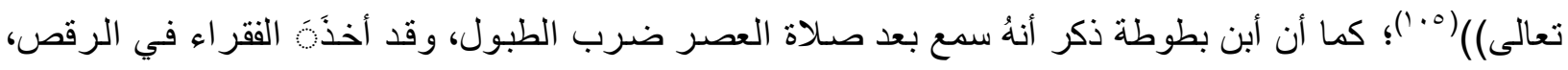
بعد أن تتاولو ا الطعام و أدو ا صلاة العثاء،أخذو ا بالذكر، و أعدوا أحمالاً من الحطب فأنتعلو ها، وقد دخلو ا في جوفها وفها

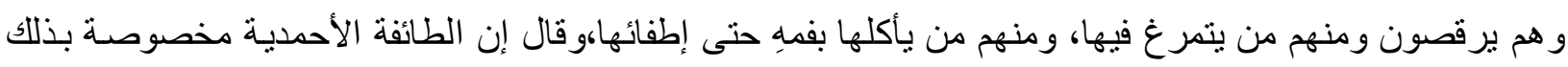

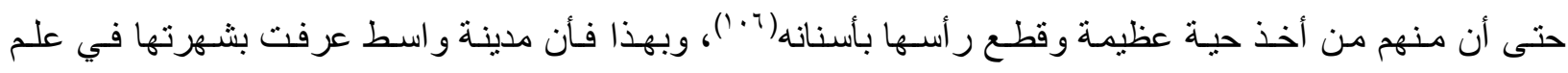

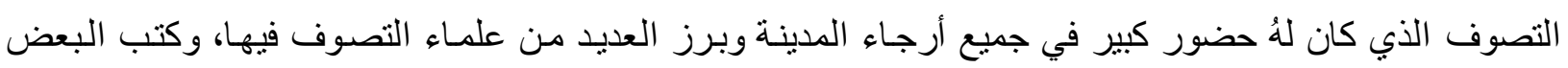

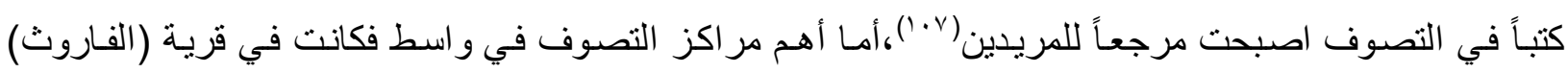
الو اقعة بين واسطو المذار(^•). أما أشهر علماء التصوف في و اسط خلال مدة موضوعة الدراسة فهز:

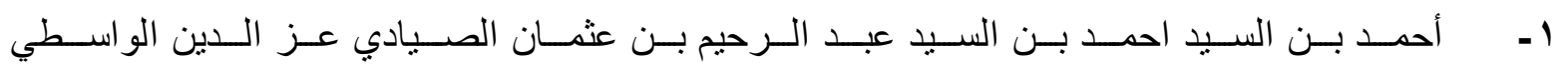

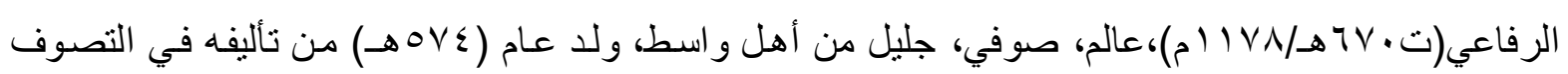

$$
\text { (الوظائف الأحمدية في مناقب الرفاعية) ( ('). }
$$

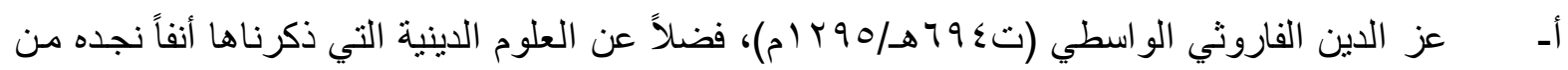
المتصوفة، وقد عرف عنه أنهُ كان عالماً متضلعاً بالعلوم والآداب و اهتم بالرحلة في طلب العلم ونشره حسن

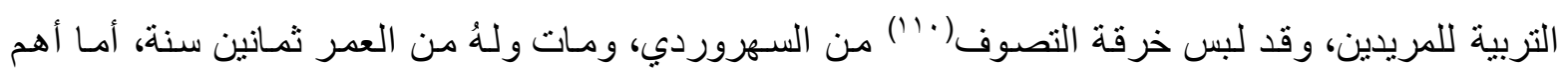
مصنفاته في التصوف(')"' .إرشاد المسلمين لطريقة شيخ المتقين. و النفحة المسكية في السلالة الرفاعية. أـ عماد الدين أبو العباس احمد بن عبد الرحمن بن مسعود الواسطي(ت ا لVهـ)، الحنبلي، البغدادي، الدمشقي، وكان

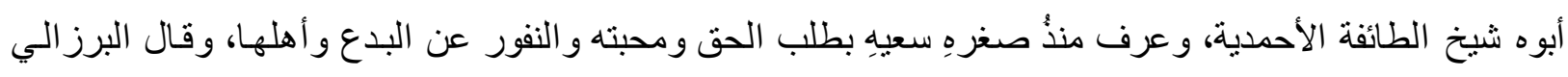
عنهُ في معجمه، أنهُ عارف صاحب نسك و عبادة منقطعة و عزوف عن الدنيا ولـهُ كلام متين في التصوف الصحيح،

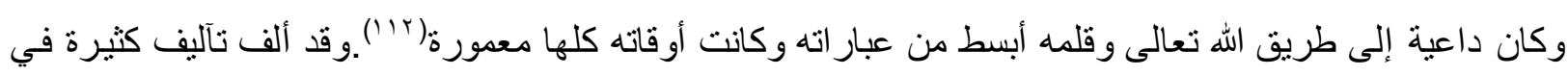

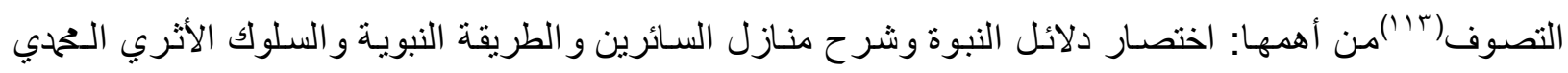

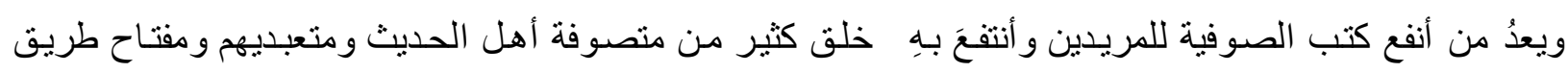


المحبين وباب الأنس برب العالمين المؤدي إلى أحوال المقربين في التصوف ومفتاح طريق الأولياء وأهل الزهد من العلماء.

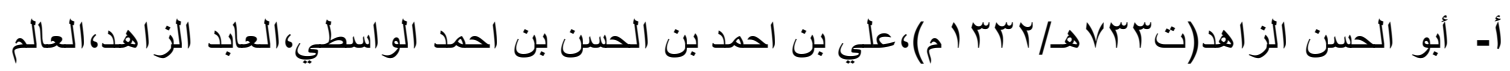

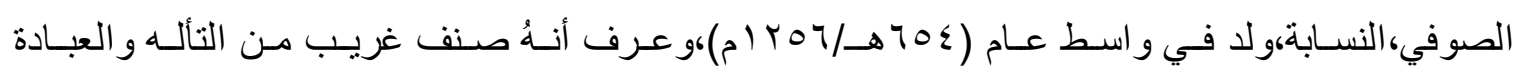
و الأنقباض على الناس وفي ذهنه علوم نافعة صحب الثيخ عز الدين الفاروثي وتواترت عنـهُ الكر امـات وله تصانيف في التصوف(\&) (1)، ومن أهم تلك التصانيف.لاصة الإكسير في نسب الرفاعي و الكبائر و الصغائر.

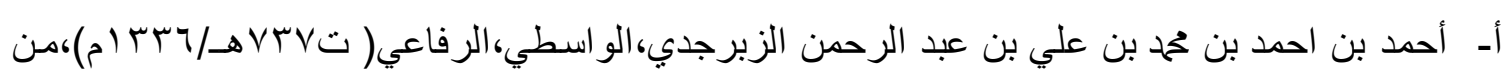

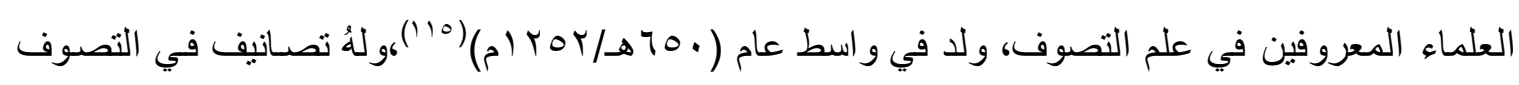
منها: صنف الدر الساقط في مناقب سادات واسط، ويعني بـ:سادات و اسط السادة الرفاعية.

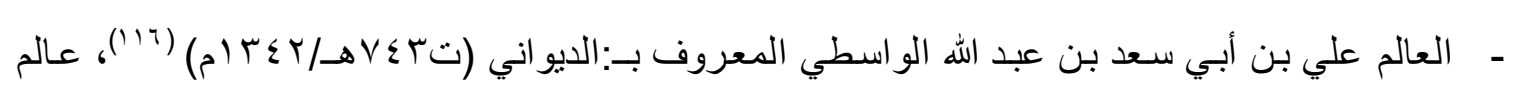
جليل صـوفي،من أهـل و اسط لـهُ تصـانيف في التصـوف أهمها: جمـع الأصـول( قصـيدة لاميـة في نظم الإرشاد).

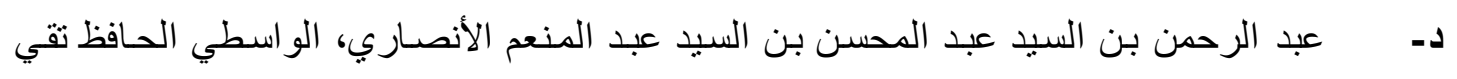

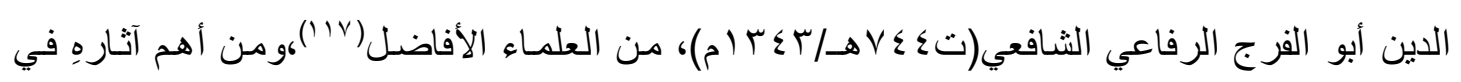

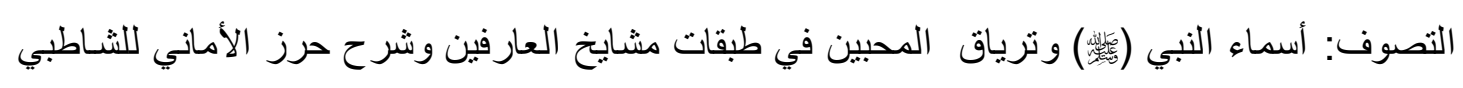
ومناقب السيد احمد الرفاعي.

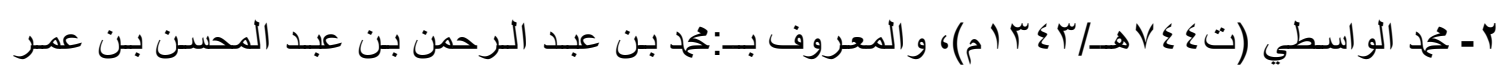

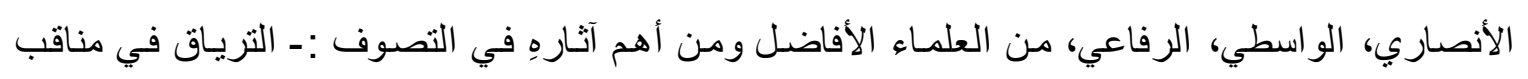

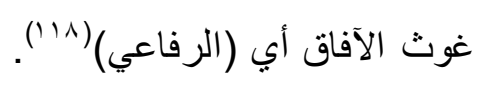

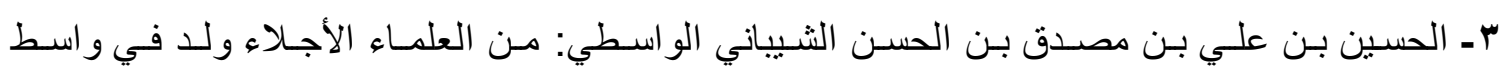

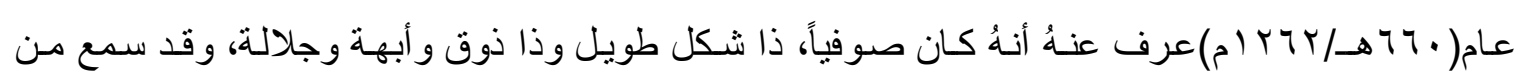
الفاروثي و غيره من الكبار (19).

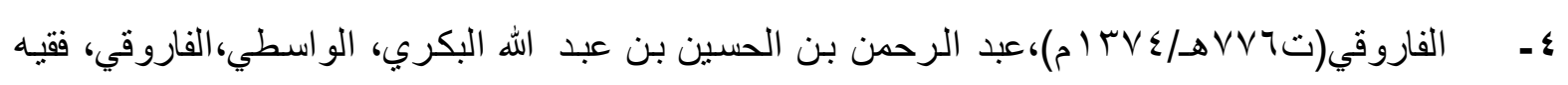

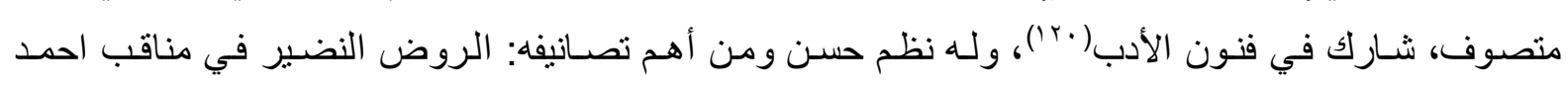
الرفاعي.

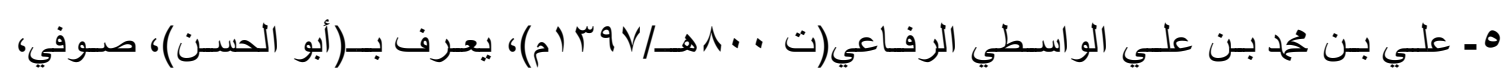

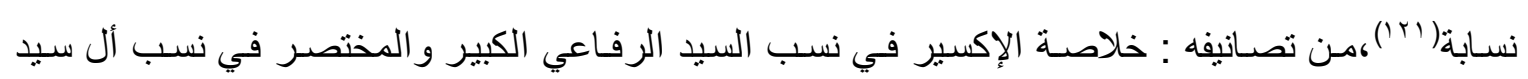
البشر. 
- احمد بن عبد المنعم شهاب الدين الواسطي، أبو الهدى المعروف بالسمديسي، من العلماء الواسطيين

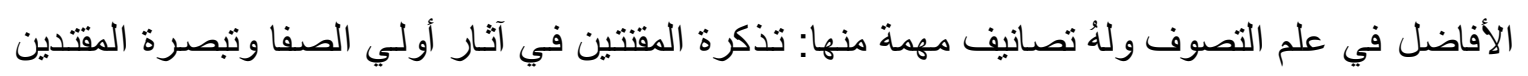

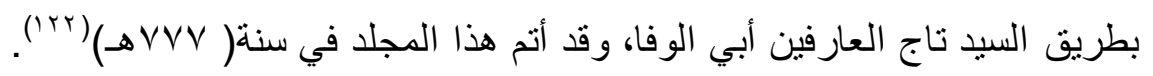

|الغاتمـة

لقدعرف عن و اسط بالحياة العلميـة ومر اكز هـا المهمة كالمسـاجد و المـدارس و البيمارستانات، فضـلاً عن المر اكز الأخرى ذات الأثر العلمي كخز ائن الكتب (المكتبـات)، وبيـوت العلمـاء و أسـواق الكتب وحو انبـت

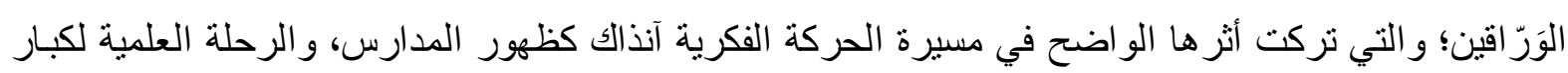
الققهاء والعلمـاء في شتى فنون العلم، ومـا تركته تلك الرحلة من آثار ايجابية في مسبرة الحركة الفكرية في تركي و واسط في تللك المرحلة الزمنية، ومن خلال تحليلنا للمعلومات الواردة في المصادر التاريخية عن كل شخصبة من شخصيات العلماء والفقهاء وعن أهم المر اكز الفكرية في المدينة فقد أثبتنـا العديد من النتائج التي تؤكد لنـا وجود حياة فكرية و علمية نشيطة في تللك المدة ومن هذه النتائج:

- شهدت الدر اسات الدينية المتمثلة بعلوم القر آن و الفقه و الحديث و التصوف نهضة شاملة في و اسط في

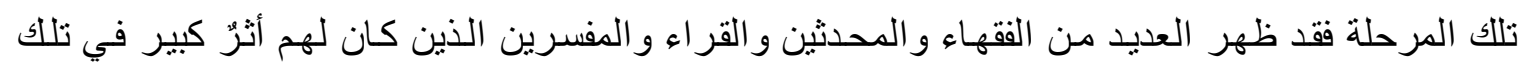

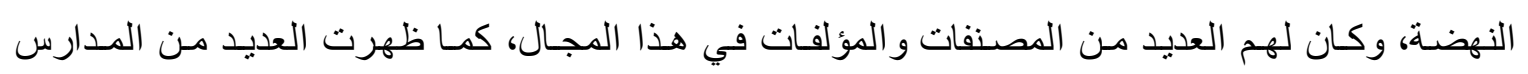
الصوفية في المدينة لكون و اسط مركز اً مهماً من مر اكز التصوف في المدن الإسلامية.

- - يمكن الاستنتاج بأن واسط مدينة فكرية استطاعت أن تحمي تر اثها الفكري و الحضاري على الرغم من التقلبات السياسية و السيطرة المغولية والخلافات المذهبية ، و الدليل على ذلك ظهور العديد من العلمـاء

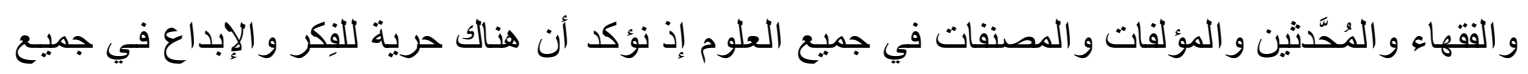
المجالات ، أما تشييد المدارس والمساجد والمر اكز الفكرية الأخرى فهو دليل آخر على استمر ار النهضية

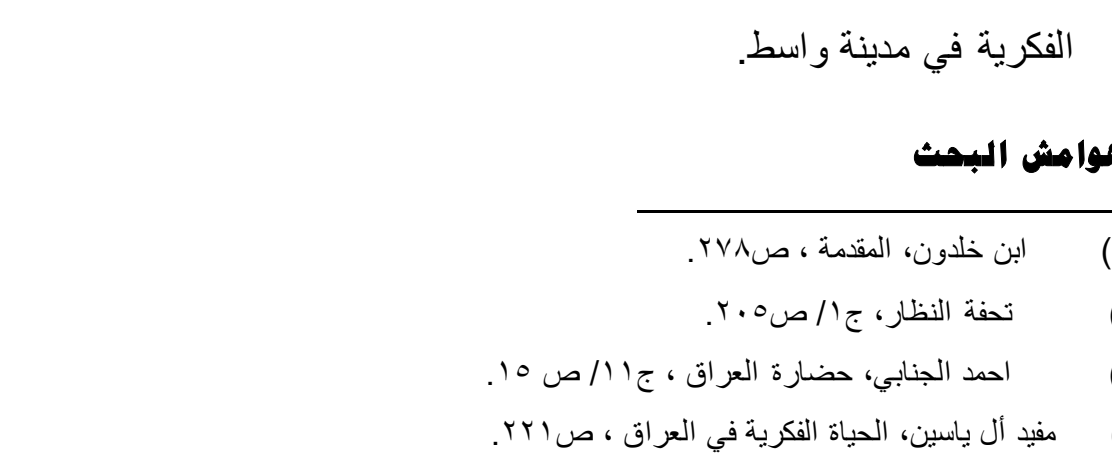

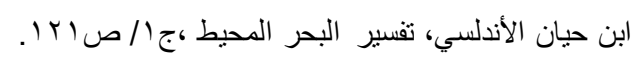

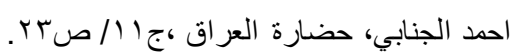

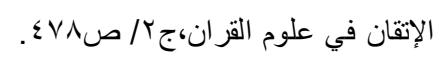

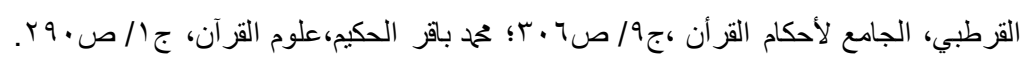




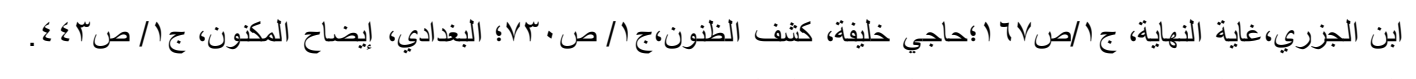

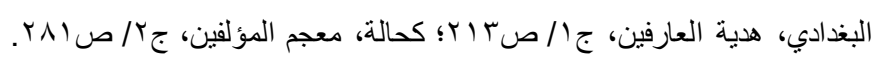

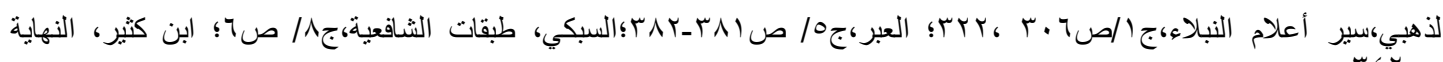

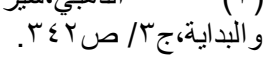

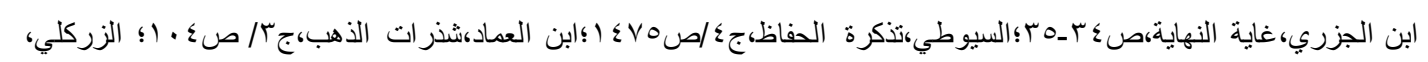

$$
\begin{aligned}
& \text { جزيرة تقع في جنوب الخليج العربي، وتعرف هذه الجزيرة بأهميتها التجارية وقد كانت تعرف بـجزيرة كيش، الحموي، معجم }
\end{aligned}
$$

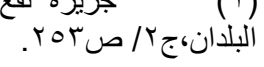

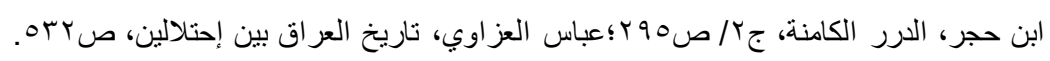

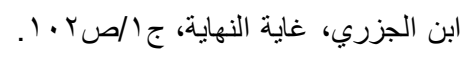

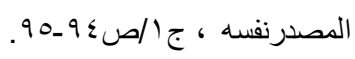

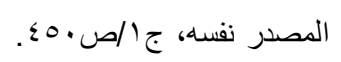

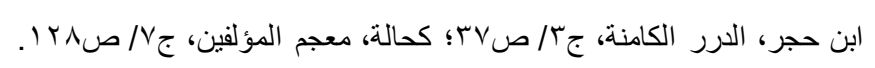

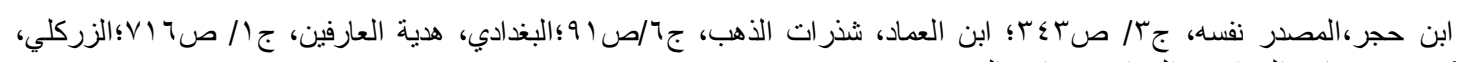

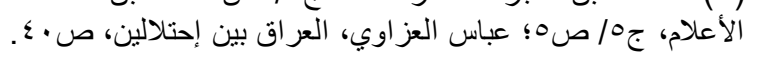

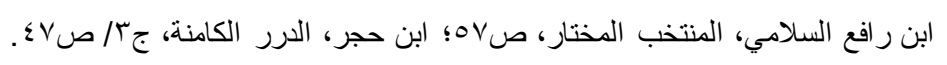

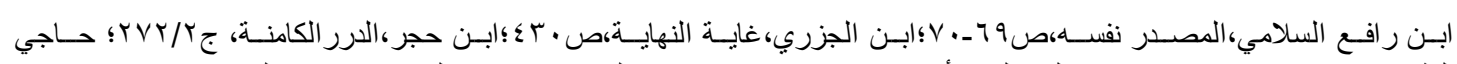

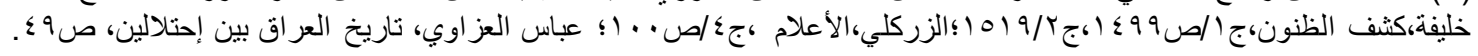

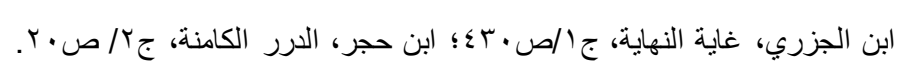

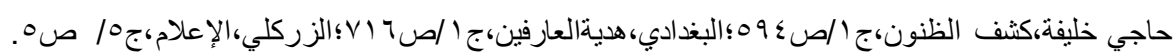

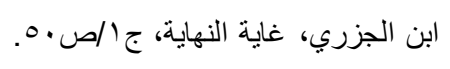

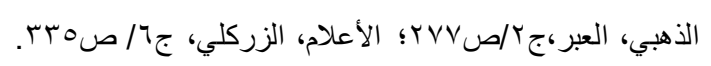

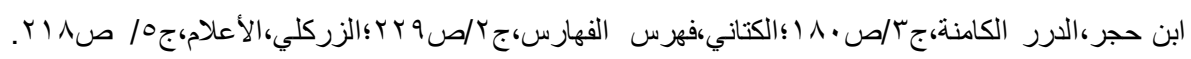

$$
\begin{aligned}
& \text { ابن الجزري،غاية النهاية، ج(/صזیه. }
\end{aligned}
$$

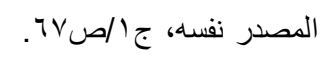

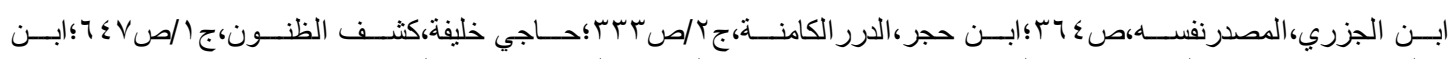

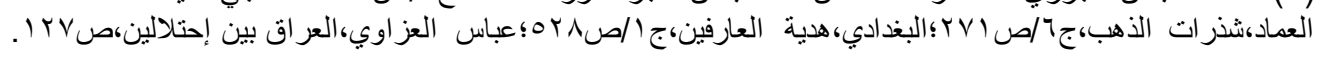

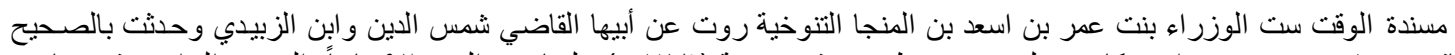

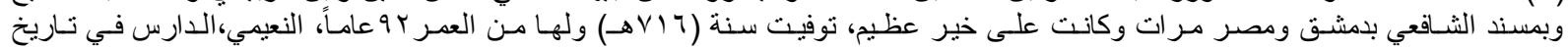

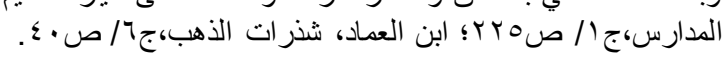




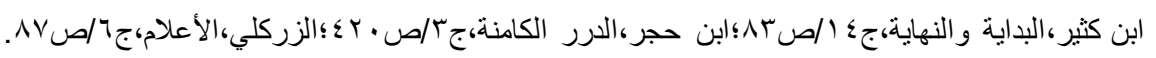

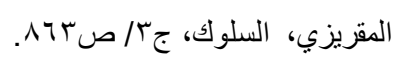

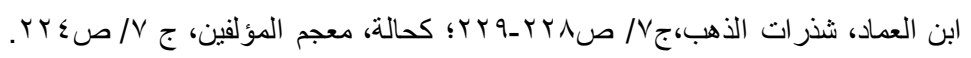

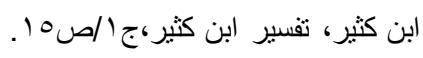

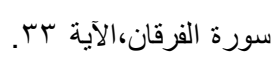

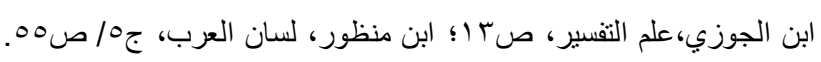

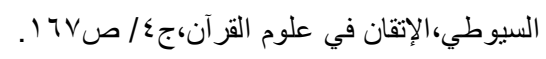

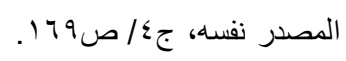

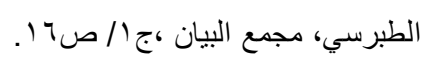

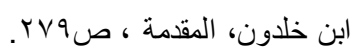

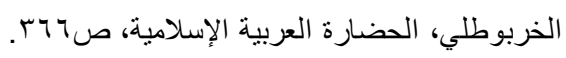

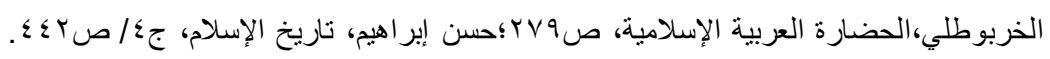

$$
\begin{aligned}
& \text { ابن رافع السلامي، المنتخب المختار،صعـ؛ حاجي خليفة، كثف الظنون، ج / / ص. } 9 .
\end{aligned}
$$

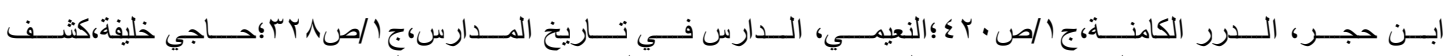

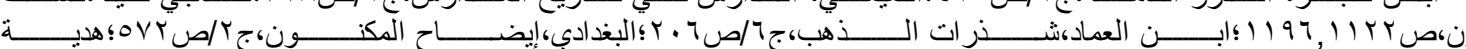

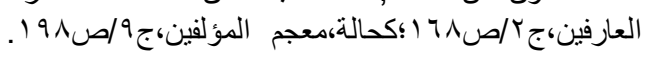

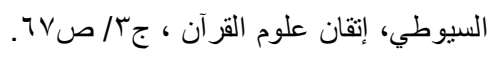

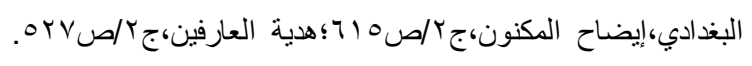

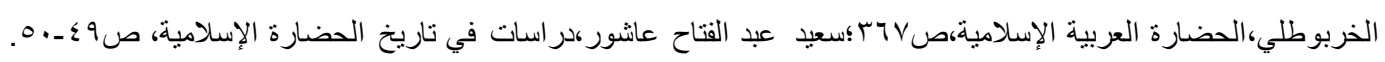

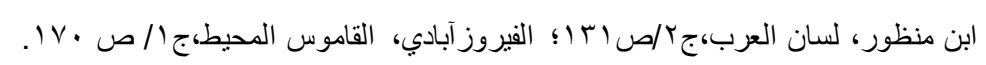

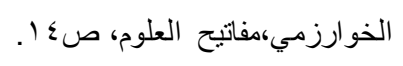

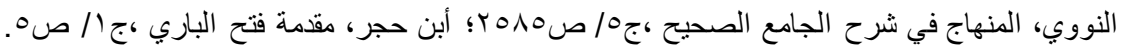

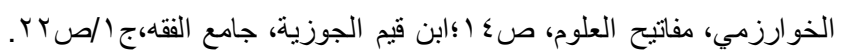




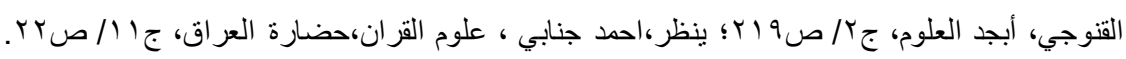

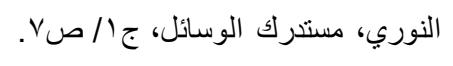

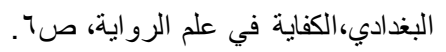

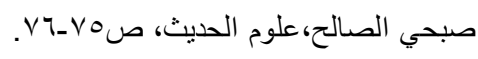

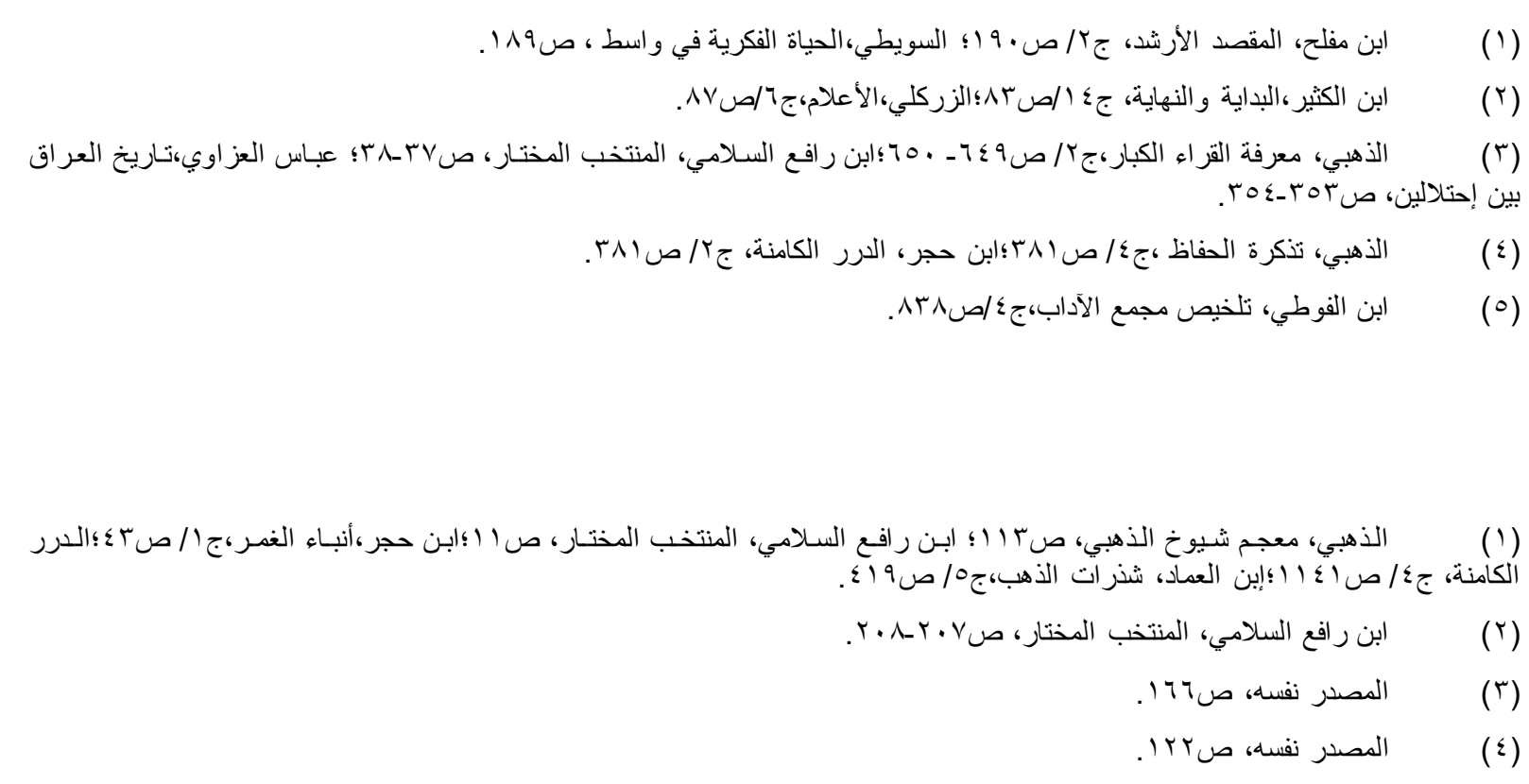

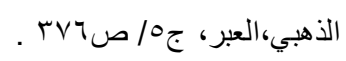

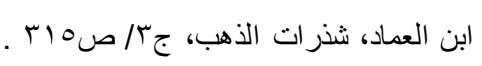

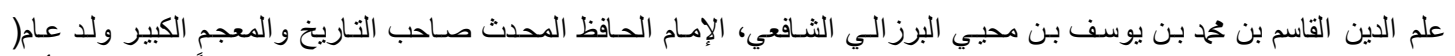

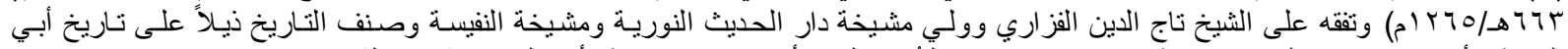

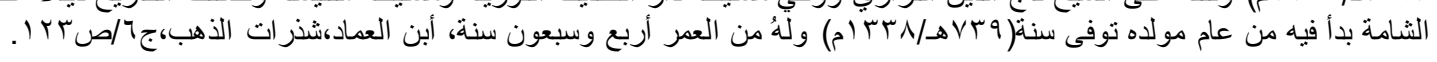

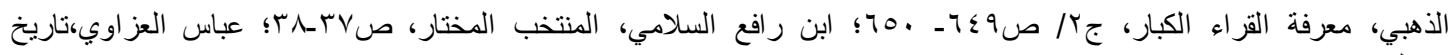

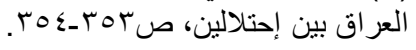

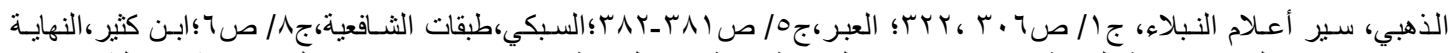

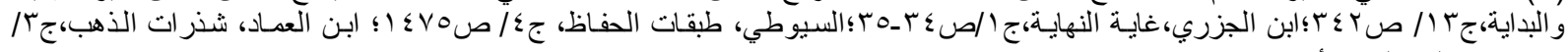

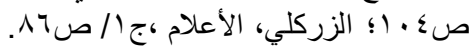




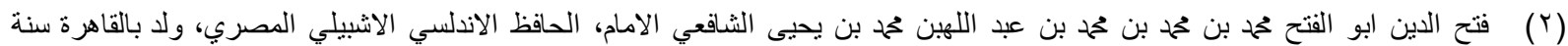

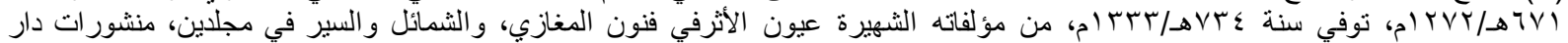

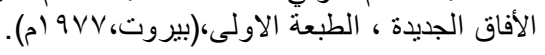

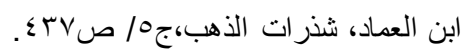

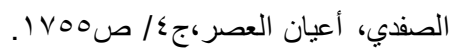

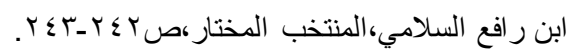

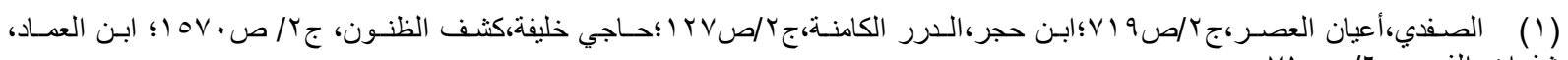

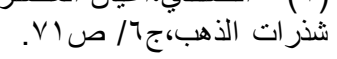

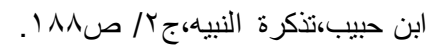

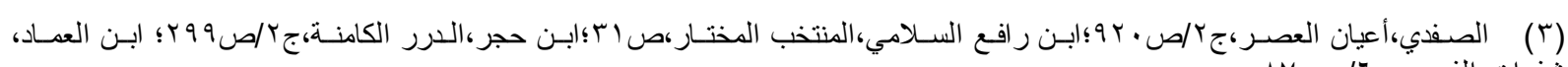

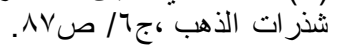

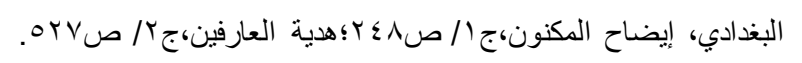

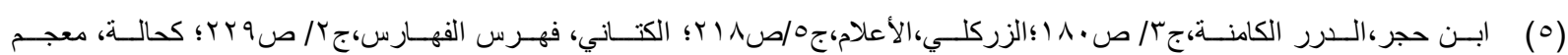

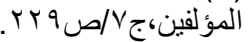

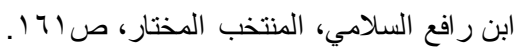

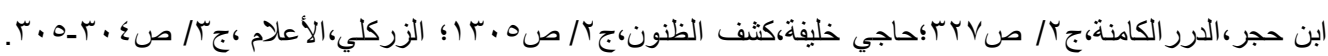

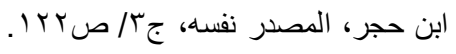

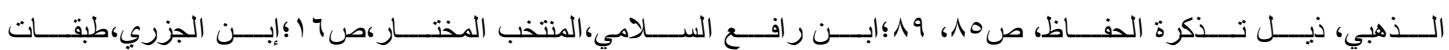

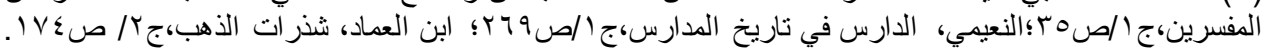

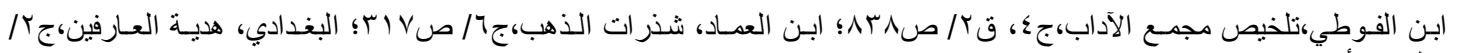

$$
\begin{aligned}
& \text { الخوارزمي، مفاتيح العلوم،صع (؛ ابن قيم الجوزية،جامع الققه، ج / صبr. }
\end{aligned}
$$

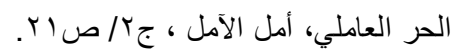

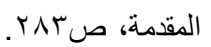

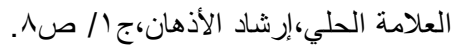

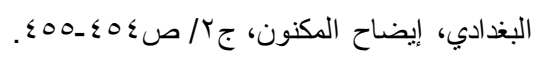

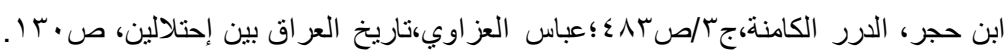

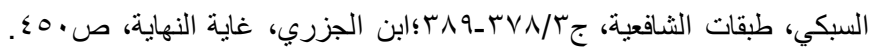

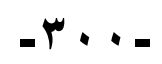




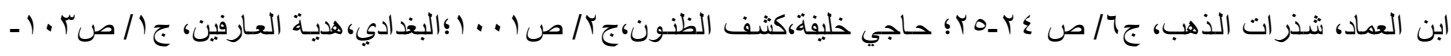

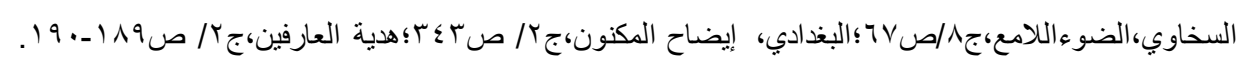

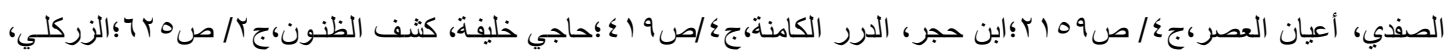

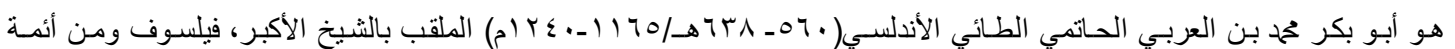

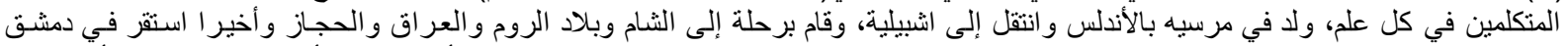

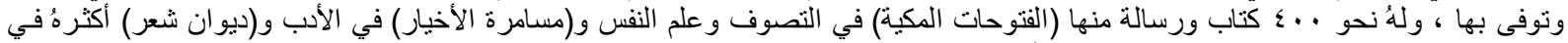

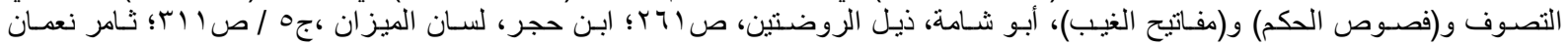

$$
\text { مصطاف، زكريا القزويني، صـء }
$$

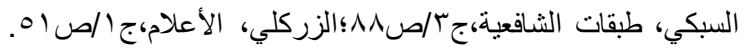

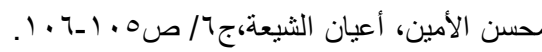

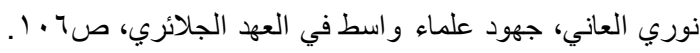

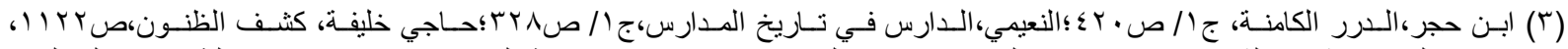

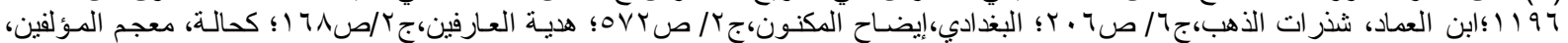

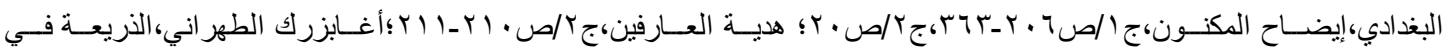

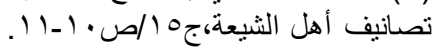

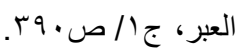

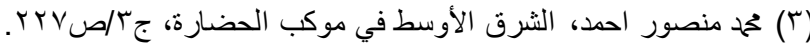

\footnotetext{
الكلاباذي، التعرف لمذهب أهل التصوف، صVrr.

عبد اللطيف حمزة،الحركة الفكرية في مصر في العصرين الأيوبي والمملوكي الأول، ص 90.

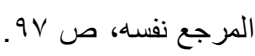

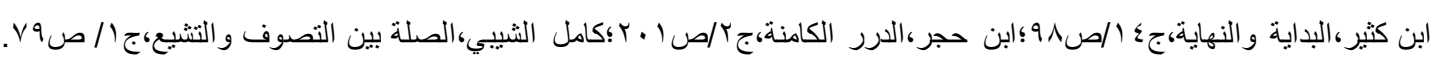

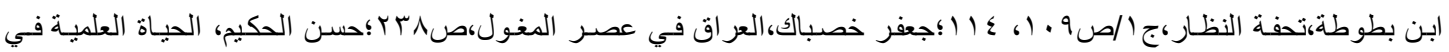

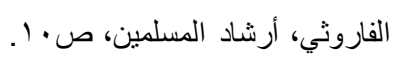

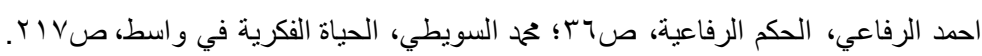




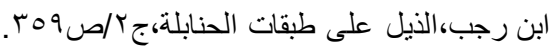

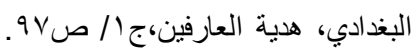

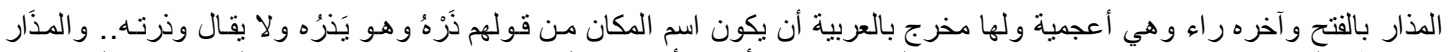

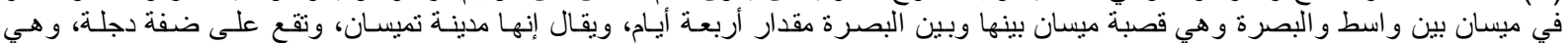

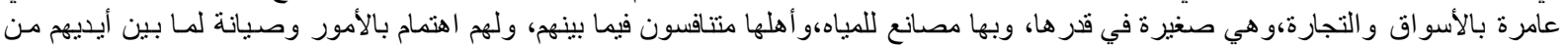

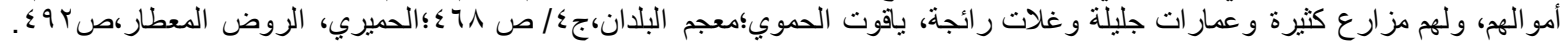

$$
\text { تقي الدين الواسطي، ترياق المحبين، ص. كـ. }
$$

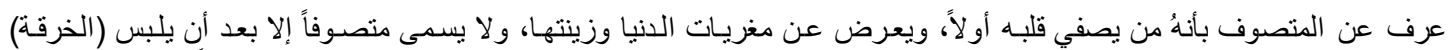

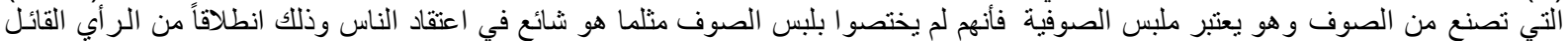

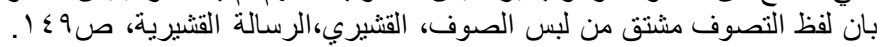

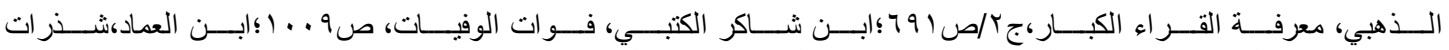

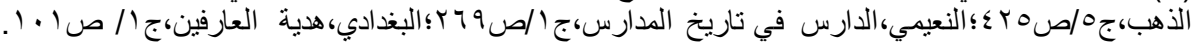

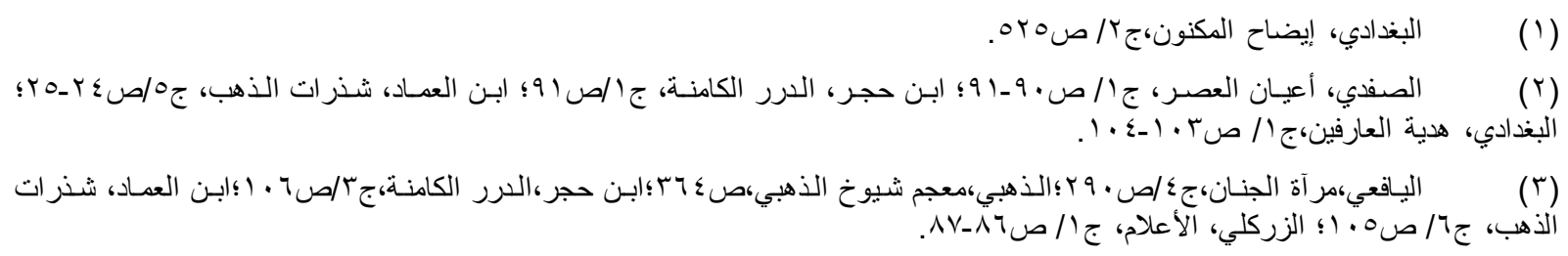

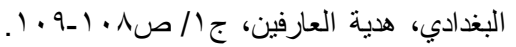

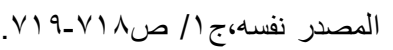

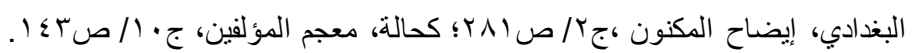

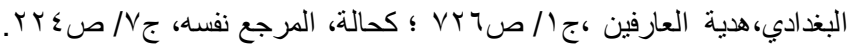

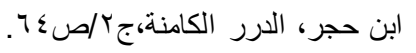

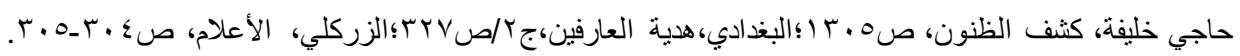

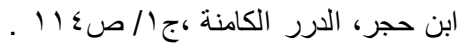

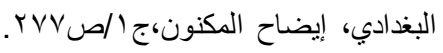

خير مابتأ بهِ: القرآن الكريم

اولاً : المصادر

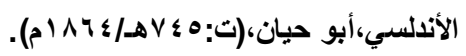

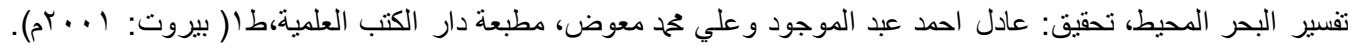

$-1$ 


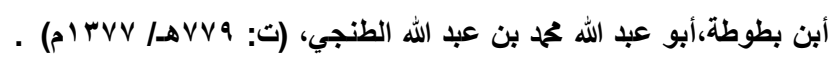

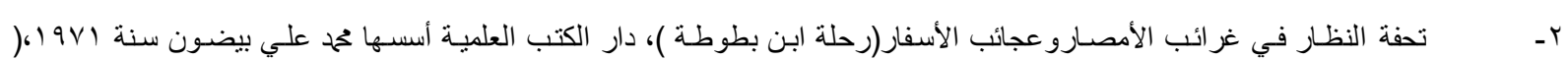
بيروت: V V V V V).

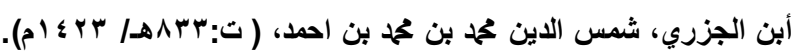

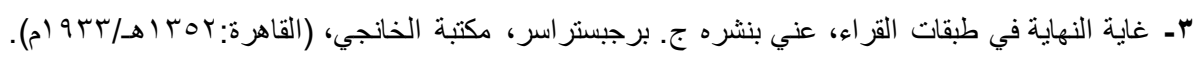

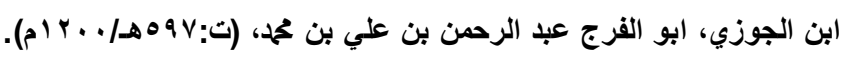

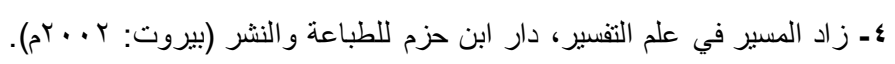

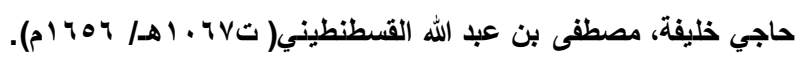
هـ كثف الظنون عن أسامي الكتب والفنون، دار الكتب العلمية،( بيروت :99 (99). ابن حبيب،الحسن بن عمرو بن الحسن بن عمرو،(ت: هـVVq هـ

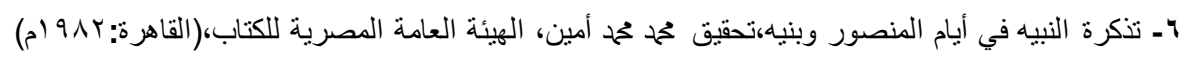

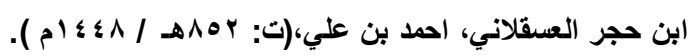
V- إنباء الغمر بأنباء العمر، تحقيق حسن حبثي،مطبعة لجنة إحياء التراث العربي الإسلامي، (القاهرة: 1991 (1م).

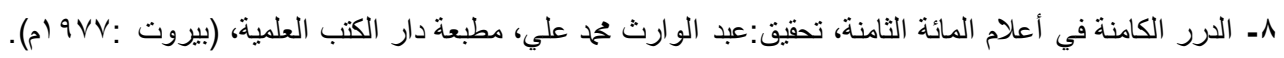

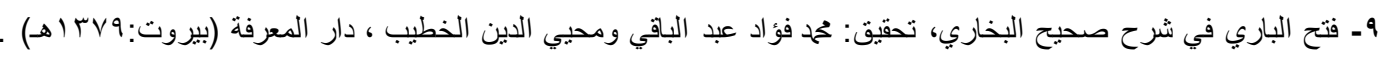

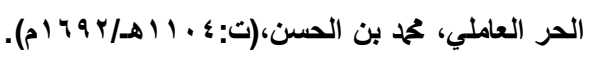

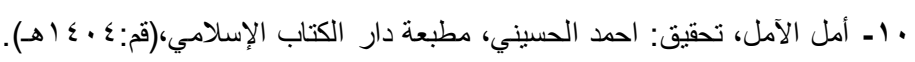

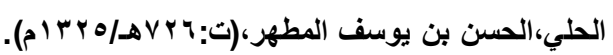

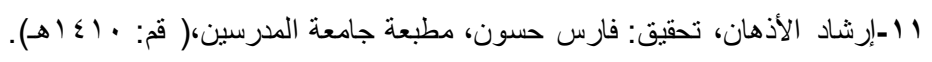

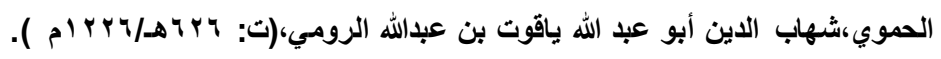

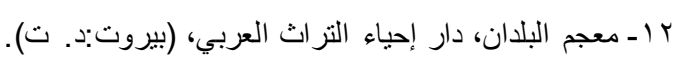

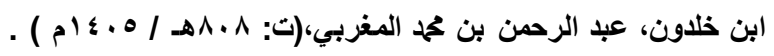

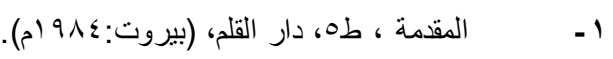

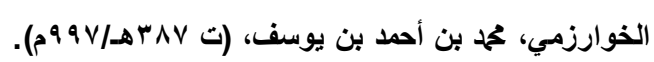
ع ا - مفاتيح العلوم، تقديم و إعداد: عبد اللطيف لحمح العبد، دار النهضة العربية، (القاهرة : د. د. ت).

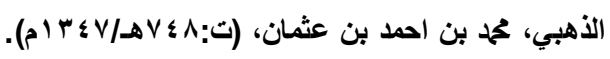

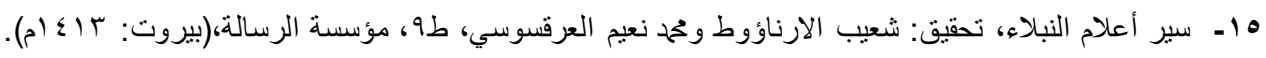

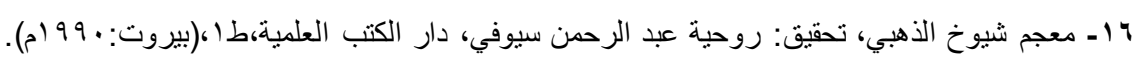

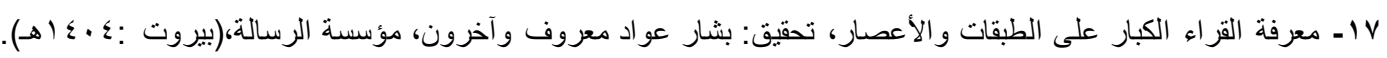

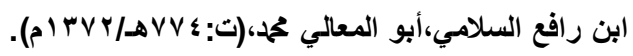

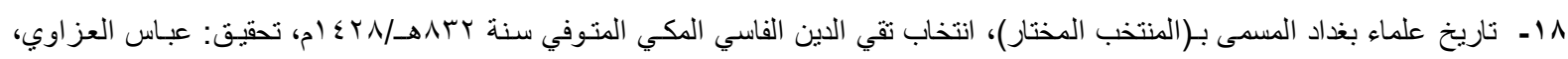

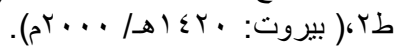

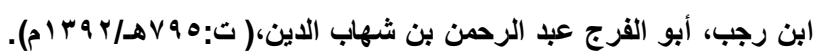

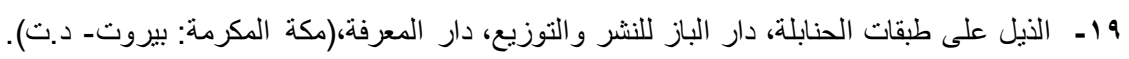

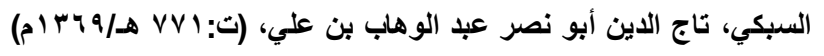

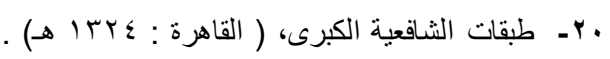

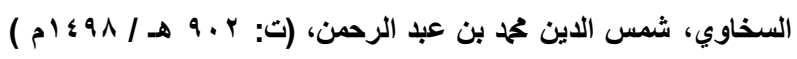

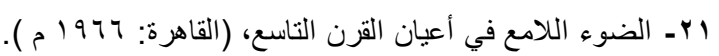

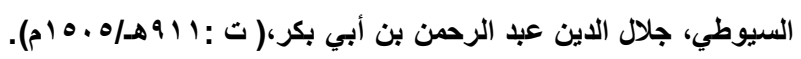

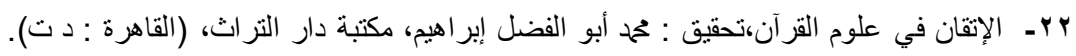

\section{- r. M.}


بr - طبقات الحفاظ، دار الكتب العلمية، (بيروت:؟ • ـ ( ).

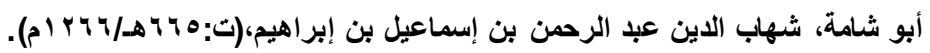

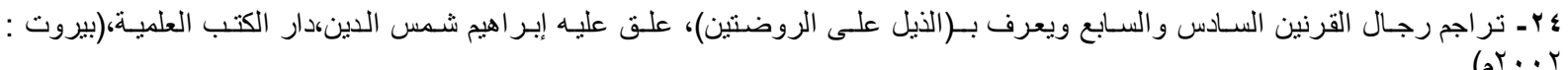

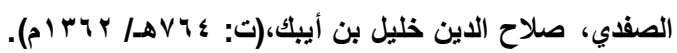

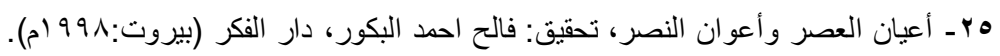

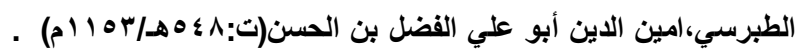

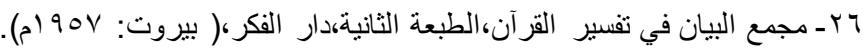

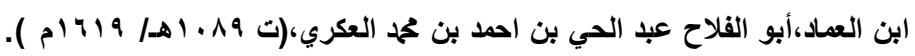

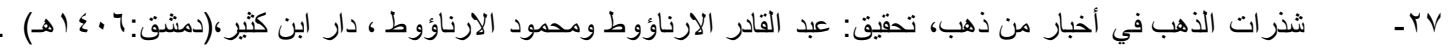

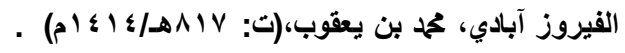

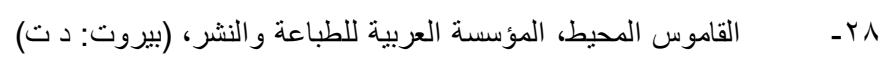

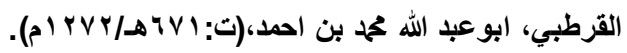

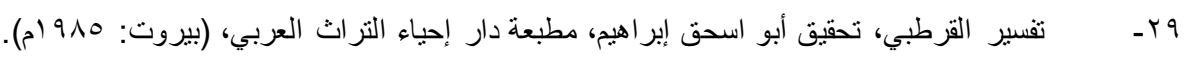

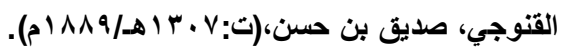

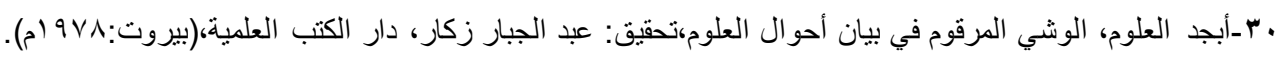

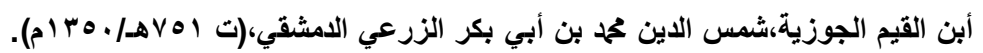

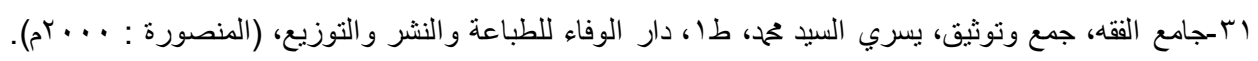

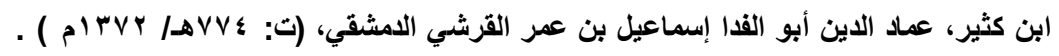

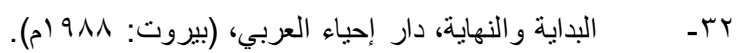

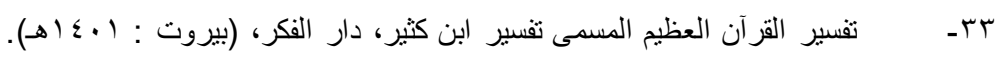

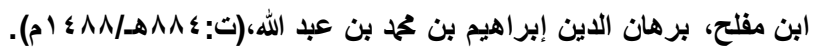

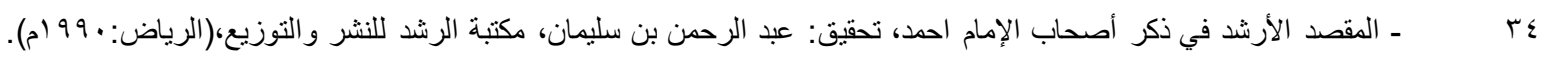

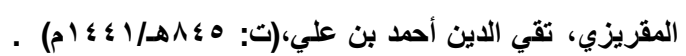

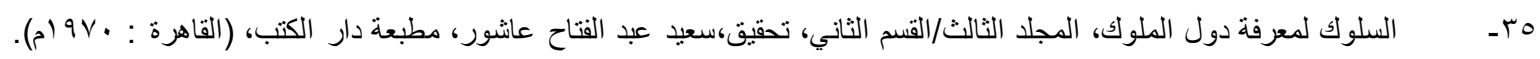

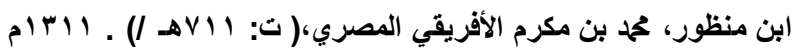

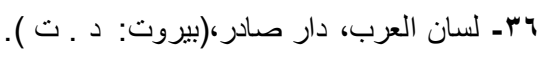

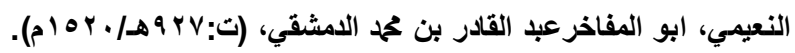

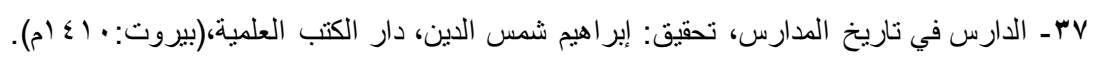
النووي، محيي الدين يحيى بن شرف، (ت: צ

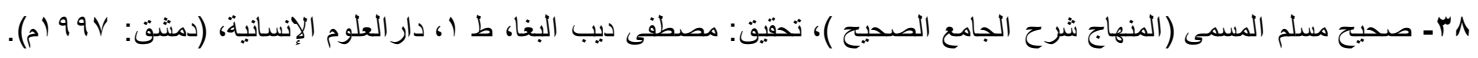

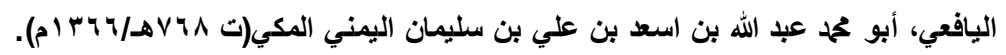

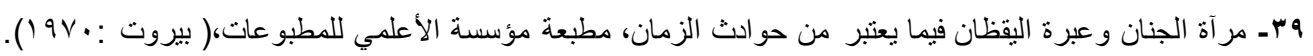
ثانياً / المراجع الحديثة

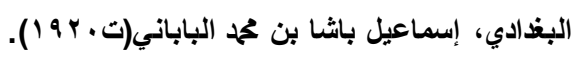

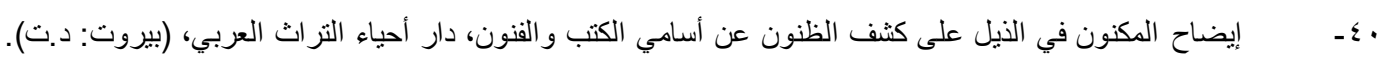

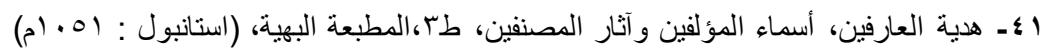

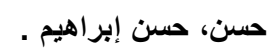




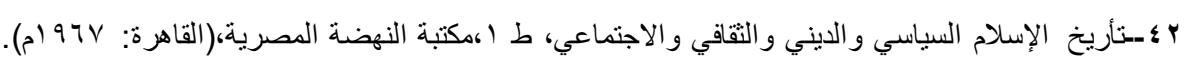

الحكيم، أية الله محمد باقر ب ــ - علوم القرآن ، طب، دار التعارف للمطبو عات،(بيروت:990 (م). الحمداني، طارق نافع الخربوطلي، علي حسني .

؟ ـ ـ الحضارة العربية الإسلامية، دار الطباعة الحديثة، (القاهرة: د ت تر). الزركلي، خير الدين 0ـ ـ الأعلام، قاموس تر اجم لأشهر الرجال و النساء من العرب و المستعربين والمستشرقين، ط ء، دار العلم للملايين، (بيروت: 9V9 (م). السويطي،كمج حسين علي

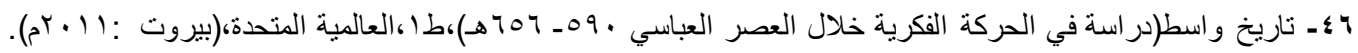
الصالح، صبحي

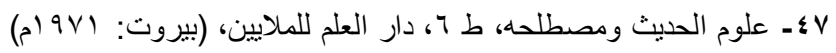
عاشور، سعيد عبد الفتاح وآخرون

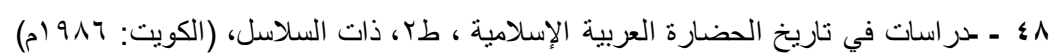

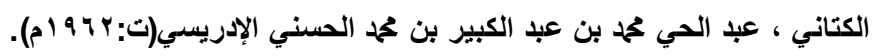

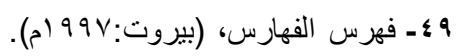
كحالة، عمر رضا . • هـ معجم المؤلفين تر اجم مصنفي الكتب العربية، دار إحياء التراث العربي ، (بيروت: د.ت). مصطاف،ثامر نعمان اهـ زكريا القزويني ومساهماته العلمية،ط ،دار تموز للطباعة و النشر و التوزيع،(دمشق:r ا • rم). النوري، حسين بهـ مستدرك الوسائل، مطبعة مؤسسة أهل البيث (عليهم السلام)لأحياء التراث،(بيروت: 911 (م).

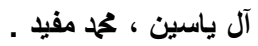

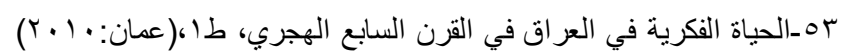
الجنابي،احمد نصيف ــــ علوم القرآن الكريم، ضمن كتاب حضارة العر اق، تأليف نخبة من الباحثين، ج) (ا، دار الحرية للطباعة،(بغداد:919 (م). السويطي، حمح حسين هـــ مدرسة الثيخ تقي الدين الو اسطي وسيرة مؤسسها في رواية ابن بطوطة المغربي ، بحث منشور ضمن وقائع المؤتثر العلمي الثناني لكليـة

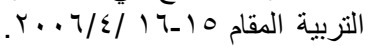

